\title{
Using Unexpected Recalls to Examine the Long-Term Earnings Effects of Job Displacement \\ Yolanda K. Kodrzycki
}

No. 07-2

\begin{abstract}
:
This paper examines the long-term earnings consequences of permanent layoffs initiated during the early 1990s, using a sample of Massachusetts workers who enrolled in Job Training Partnership Act Title III programs, and who remained strongly attached to the state's labor force. The comparison group is formed by workers who were unexpectedly recalled. On average, recalled workers incurred substantial annual earnings reductions upon reemployment. Nevertheless, one decade later, permanently displaced workers were still earning between 11 and 17 percent less per year than recalled workers with comparable pre-layoff skills and experience. Workers with limited education experienced particularly large earnings reductions from permanent job loss.
\end{abstract}

JEL Codes: J24, J31, J64, J65

Yolanda K. Kodrzycki is senior economist and policy advisor at the Federal Reserve Bank of Boston. Her e-mail address is Yolanda.Kodrzycki@bos.frb.org.

The views expressed in this paper are those of the author and do not necessarily represent the views of the Federal Reserve Bank of Boston or the Federal Reserve System.

The author is very grateful to Johan Uvin, former director of research at the Commonwealth Corporation, and to CommCorp research and evaluation staff members Gene White and Devrim Karaaslanli, for their extensive collaboration in this project. Nelson Gerew provided excellent research assistance. Katharine Bradbury, Mary Burke, Chris Cunningham, Chris Foote, Kathryn Lasch, Bridget Long, Donald Parsons, John Robertson, Alicia Sasser, and Scott Schuh offered valuable comments on previous versions.

This version: August 8, 2007 
A substantial literature in economics has analyzed the sources of earnings loss when an employment relationship is severed (Fallick, 1996; Kletzer, 1998). When workers are displaced from their jobs, they lose the value of the human capital investment that is specific to their former employer or industry. Long-tenured workers lose the value of a high-quality job match, whether or not they were employed in positions that required skill, and some displaced workers lose the added income associated with unionization, other forms of rents, and industry wage premia. Finally, layoffs may cause workers to forgo various forms of deferred compensation, either contractual or implicit. Although the exact magnitudes vary from sample to sample, a survey of the major literature concludes that "[t]he weekly earnings losses of displaced workers average 14 percent or more even after four years" (Fallick, p. 13).

This paper enhances the understanding of the longer-term earnings effects of job loss by tracking a group of Massachusetts workers for roughly a decade after they were permanently displaced in the early 1990s. A distinguishing feature of the study is its focus on workers who qualified for assistance under the dislocated worker amendment to Title III of the Job Training Partnership Act (JTPA). This federal program was targeted at experienced workers who were involuntarily laid off with little or no probability of recall by their former employer, and who faced substantial barriers to finding similar jobs. Moreover, the study focuses on job losses that occurred in the context of particularly high unemployment and extensive layoffs in the northeastern United States. Therefore, unlike previous studies that have used general-purpose surveys such as the Current Population Survey (CPS) or the Panel Study of Income Dynamics (PSID), this paper concentrates on workers who were highly unlikely to find jobs similar to the ones they had left. On average, these workers would likely incur a larger drop in earnings at their new employment than is typical of job losers.

An important issue in assessing the consequences of job loss over the long term is the selection of an appropriate earnings stream against which to benchmark the earnings of workers who are laid off and then find new employment. Jacobson, LaLonde, and Sullivan (1993a, 1993b) have argued persuasively that the costs of job displacement should be 
measured with reference to what workers would have been earning in the absence of a layoff-rather than relative to their pre-layoff earnings. From the standpoint of empirical implementation, this concept of forgone earnings is inherently ambiguous, and it appears to involve the construction of an unobserved alternative situation for the laid-off workers (Farber 2003).

One such benchmark might be the earnings that would result from renegotiating employment terms with a firm that otherwise would enact a layoff (Hall 1995). The resulting earnings stream would arguably be lower than the earnings stream that workers might reasonably have expected during some "pre-layoff" period. Therefore, if it could be constructed, such a hypothetical would tend to reduce the measured earnings consequences of layoff, relative to a measure based on expected earnings as of the last observed wage agreement [regarding the terms of employment].

Instead of deriving the terms of a renegotiated labor contract that would avert inefficient layoffs, the literature has tended to use the experiences of never-displaced workers for the counterfactual scenario. This approach has the advantage of relying on an observed benchmark. Furthermore, it has intuitive appeal and may indeed conform to the scenario used in popular discussions of the effects of job loss. However, this approach to measuring the consequences of job loss raises the question of what combination of individual traits, employer circumstances, and macroeconomic factors insulated members of the comparison group from being selected for layoff.

To overcome the drawbacks associated with the methods discussed above, the current study compares the earnings of displaced workers with the earnings of other workers who were initially laid off by Massachusetts employers between 1992 and 1994 and who registered for JTPA services, but then were unexpectedly recalled shortly thereafter. Reflecting the depressed state of the Massachusetts economy and the ongoing structural changes in manufacturing and other defense-dependent industries taking place in the early 1990s, only 4 percent of the sample were observed to have been recalled by their former employers as of late 1994. Although Ong and Mar (1992) also examined the effect of recall versus permanent displacement, they did so in the context of a recession for a particular 
sector (semiconductors) but not the broader economy. In their sample, the majority of workers who were let go were subsequently rehired by their previous employers.

By using unexpectedly recalled workers as a comparison group, the study casts light on an important and longstanding economic issue: the consequences to workers of involuntary separation versus involuntary reduction in wages or work hours. In effect, all the workers in the sample sustained a negative shock to the value of their earnings as a result of weakness in their industry of employment or in the economy, but only some were permanently laid off. Others - the recalled workers - managed to retain their jobs, albeit after a short period of involuntary unemployment and initially with their pay or hours reduced to reflect their employers' economic difficulties. Comparing the earnings losses of these two groups enhances our understanding of the sources and magnitude of the welfare costs of business cycle fluctuations, a topic addressed both theoretically and empirically on the macroeconomic level in Krebs (2007).

The closest existing analogue to the approach used in this paper is the work of Jacobson, LaLonde, and Sullivan (1993a, 1993b), which compares the earnings of experienced workers who lost their jobs in mass layoffs in Pennsylvania between 1982 and 1986 with the experiences of their co-workers who remained continuously employed by these firms during this entire period. An updated analysis of these mass layoffs indicates that separators earned 45 percent less than did stayers in years 0 through 2 after job loss, 25 percent less in years 3 through 6, and 18 percent less in years 7 through 11 (Sullivan and von Wachter, 2007). Employees who survived mass layoffs experienced only modest declines in earnings relative to workers who stayed at other Pennsylvania firms that made smaller or no reductions in their workforces during these same years. Therefore, the estimated earnings losses from being let go in a mass layoff were not very sensitive to the choice between using earnings at the former, distressed employer and using earnings of the Pennsylvania workforce in general as a benchmark. ${ }^{1}$

\footnotetext{
${ }^{1}$ Furthermore, the results obtained using the mass layoff subset of the Pennsylvania data were not very different from those obtained using the entire Pennsylvania dataset, including separators who were not part of mass layoffs. The estimated earnings losses from being laid off versus being retained
} 
There are several reasons to expect the current study to yield different-and likely smaller-estimates of the earnings differences between displaced and continuing workers at distressed firms than in the Jacobson, LaLonde, and Sullivan research. For one thing, the comparison group is arguably more similar to the permanently dislocated worker group, since its members also were selected for layoffs, met the JTPA requirements, registered for job search assistance, and often were recommended for retraining or remedial education services. In addition, the study employs a rich set of individual controls, including not just sex and age, but also additional measures of human capital such as education and tenure at the previously-held job. To reduce further the scope for unobserved heterogeneity in skill levels across workers, the paper uses each worker's score on a reading test administered as part of JTPA services as a direct indicator of transferable human capital. Existing studies of job loss have not controlled for differences in the post-schooling accumulation of general human capital, except to the extent that such differences were reflected in pre-layoff earnings. ${ }^{2}$ These pay differentials between workers may have partly reflected differences in the extent to which their jobs made use of their skills, in addition to any differences in their skill levels or in firm-specific rates of return to skills. (Kuhn and Sweetman (1999) use the term "alternative skills" to refer to abilities that are not used in a particular job, but that may be useful in an alternative context.) It is shown below that using different sets of controls for human capital has little effect on estimated earnings consequences in the first several years after displacement, but that these human capital indicators exert larger effects in the longer term.

Previous studies have indicated that earnings losses vary, depending upon how closely laid-off workers' job matches in the post-displacement period conform to those of a reference group whose members never lost their jobs during the same period. Earnings reductions

by a firm implementing mass layoffs were only about one-fifth lower than the earnings losses measured by comparing all who separated from their employer to all who stayed.

${ }_{2}$ More recent studies using data from the Longitudinal Employer-Household Dynamics (LEHD) project have improved on the methodology through a statistical technique developed by Abowd, Kramarz, and Margolis (1999) and Abowd, Lengermann, and McKinney (2002) to decompose prelayoff earnings into a component attributable to observable time-varying individual characteristics such as experience, a fixed-firm effect, and a fixed-person effect. 
associated with job loss have been found to be small for laid-off workers who (like the comparison groups in these studies) avoid further periods of unemployment or nonemployment (Stevens, 1997; Carneiro and Portugal, 2003; and Huttunen, Møen, and Salvanes, 2006). In addition, this literature indicates that job losers in Europe have tended to be more successful in forming new, high-quality job matches than their U.S. counterparts.

In contrast with the approach of examining displaced workers whose subsequent labor market experiences are similar to those of never-displaced employees, the current study broadens the reference group to consist of workers who (barely) survived layoffs at their firms in the early 1990s, and whose subsequent employment and earnings experiences reflect conditions prevailing in the latter 1990s and early 2000s. The study does not limit recalled workers to uninterrupted employment with their original employer after the initial layoff and recall. Instead, the employment status and earnings of recalled workers are allowed to "evolve naturally" (Farber 2003), like those of the non-recalled workers.

Finally, the experience of a typical American worker may have changed between the 1980s and the 1990s, as permanent layoffs became more common and job security in the United States decreased (Valletta 1999, 2005). Based on their empirical findings, Jacobson, LaLonde, and Sullivan concluded that nondisplaced workers in distressed Pennsylvania firms used evidence on the incidence of past temporary layoffs to anticipate that they were unlikely to be laid off, and this lowered their willingness to agree to earnings reductions. By the early 1990s, workers may have been less able to predict their displacement status and in a weaker position to resist downward wage pressures than they had been a decade earlier.

Labor market conditions fluctuated dramatically during the sample period. The displacements occurred from 1992 to 1994, when the Massachusetts job market was severely depressed (Bewley 1995). At the subsequent business cycle peak Massachusetts unemployment reached an all-time low and was more than a full percentage point below the national average. Then between 2001 and 2003 (when the data end), Massachusetts suffered the sharpest employment loss of any state in the nation, and its workers experienced an aggregate deterioration in earnings comparable with what had occurred in the steep regional recession of the early 1990s. Thus, in addition to casting light on how job losers in the 1990s 
fared relative to those in the 1980s, this paper presents a preliminary analysis of how the longer-term consequences of job loss vary over the business cycle. This subject was addressed recently by Imbens and Lynch (2006) for a sample of young workers in the United States and by Eliason and Storrie (2006) for a representative cross section of displaced workers in Sweden, so this paper complements and extends these analyses by documenting the effects for displaced workers across a wide age span in the United States.

The study compares earnings of permanently displaced and unexpectedly recalled workers by applying econometric techniques to person-year panel data. The paper is organized as follows. Section I presents the empirical framework. Section II describes the data, a sample of Massachusetts workers who lost their jobs in the early 1990s (mostly during calendar years 1992-93) and then took advantage of federally-funded assistance programs. Following the methodology of Jacobson, LaLonde, and Sullivan (1993a, 1993b), the sample is restricted to those individuals who remained attached to the Massachusetts labor force, as indicated by their being on an employer payroll between 1995 and 2003 for at least one quarter in each earning year (defined below). Earnings histories and other employee characteristics are drawn from Massachusetts wage records and unemployment insurance claims files. Recall status is derived primarily from administrative data maintained under JTPA.

Section III presents the major findings. Relative to temporary displacement, the adverse consequences of permanent job loss were substantial and long-lasting. Yet these effects were not as large as the disparity shown in the Jacobson, LaLonde, and Sullivan studies between the earnings of those who separated involuntarily versus those who were never laid off. Furthermore, the displacement effects documented in this paper increased somewhat in the early 2000s, during the recession and lingering job decline that was particularly prolonged in Massachusetts. Using earnings of recalled workers as the benchmark, and controlling for additional determinants of earnings via regression analysis, the costs of a job loss were largest two to three years after a layoff, and then narrowed to between 12 and 16 percent in year 4. This latter result accords with the consensus findings cited above in Fallick (1996). As of year 8, the earnings differential ranged from 9 to 14 percent, depending on the 
specification used. In year 10, the estimates ranged from 11 to 17 percent. For workers displaced from manufacturing jobs in the early 1990s, the earnings losses sustained during the early 2000s downturn were statistically significant, even when a dynamic panel specification that controls for each worker's prior-year earnings was used. The paper finds that the costs of permanent job loss were larger for workers with no formal education beyond high school than for those who had completed at least some college. Finally, this study also finds relatively greater earnings losses for older and long-tenured workers, although these last results generally lack statistical significance.

Section IV presents further evidence confirming that the job recalls included in this study truly were unanticipated, rather than linked to advance information available to workers or their employers that may have been correlated with workers' future earnings potential. Section V concludes with a discussion of comparisons with previous research findings, policy implications, and future research directions.

\section{Econometric Model: Measuring Earnings Effects Over Time}

The study builds on a specification developed by Jacobson, LaLonde, and Sullivan (1993a, 1993b), and used in subsequent panel studies of the consequences of job loss (for example, Stevens 1997, Carneiro and Portugal 2003, Oreopoulos, Page, and Stevens 2005). Earnings are posited to depend on elapsed time since the initially observed job displacement, as well as on additional factors that vary across individuals and/or calendar time. This study modifies what has become the standard specification by introducing a recall indicator, thus allowing the earnings of permanently displaced workers and the earnings of unexpectedly recalled workers to follow different patterns following the initial displacement.

Log real earnings of individual $i$ in period $t$ are expressed as follows:

$$
y_{i t}=X_{i t} B+\sum_{k} D_{k, i t} \delta_{k}+R_{i} \sum_{k} D_{k, i t} \lambda_{k}+\gamma_{t}+\alpha_{i}+\varepsilon_{i t},
$$

where $X$ denotes time-varying individual characteristics; the next two terms (discussed further below) summarize the effects of job displacement and recall as functions of both 
elapsed time since displacement $k$ and calendar time $t ; \gamma$ is a set of time-period dummies; and $\alpha$ refers to unobserved individual effects. Model error $\varepsilon$ is assumed to be uncorrelated across individuals, but may be serially correlated or heteroskedastic.

Following standard notation, the indicator variable $D_{k i t}$ equals 1 in period $t$ if individual $i$ was displaced $k$ periods earlier. It equals 0 in period $t$ if the elapsed time since displacement is not equal to $k . R_{i}$ is a dummy variable equal to 1 , if individual $i$ was recalled by the former employer, and equal to 0 if the displacement proved to be permanent. As explained further below, the study considers recalls that occurred shortly after the initial displacement. Therefore, in this context, job displacement and recall can be considered contemporaneous with respect to the annual data used to estimate the model.

Given this specification, the vector $\delta_{k}$ measures the expected increase or decrease in earnings $k$ periods after the initial layoff, relative to pre-layoff earnings, controlling for the available individual and time-varying explanatory factors. The sum of $\delta k$ and the corresponding value of $\gamma \mathrm{t}$ for individual $i$ measures this expected change in earnings, given that $k$ periods after the layoff is equivalent to calendar period $t$. Previous findings in the literature indicate that this sum should be negative for at least the first several years following displacement.

The vector $\lambda_{k}$ measures the individual's additional earnings increase or decrease in each period associated with a job recall by the former employer, controlling for all other factors. This parameter is interpreted as the relative earnings effect of a temporary versus a permanent layoff $k$ periods after the initial layoff (and the negative of this parameter is referred to as the cost of permanent job displacement). For the average individual in the sample, a positive value of $\lambda_{k}$ indicates that returning to the previous workplace yielded higher earnings than available in a new job located by using the available JTPA services. Conversely, a negative value of $\lambda_{k}$ indicates that a permanent layoff, on average, benefited workers in that they found jobs with higher earnings than they would have received had they returned to their former employer. Because this parameter varies with elapsed time since the initial job displacement, the consequences of temporary versus permanent layoffs are not fixed. It is possible, for example, that permanent layoffs could result in lower 
earnings in the short term but higher earnings in the longer term, relative to temporary layoffs as permanently laid-off workers shifted into industries or occupations with higher productivity growth.

Assuming that unobserved worker characteristics are invariant over time but correlated with observable characteristics, previous authors have estimated versions of such a model specification using a fixed-effects transformation. The main set of results is based on estimating the model in this way and computing robust standard errors by clustering at the level of the individual worker. It turns out that the estimated residuals remain serially correlated, indicating possible remaining mismeasurement of standard errors. One robustness check is to estimate equation (1) as a random effects model with quasi firstdifferencing in order to correct for first-order serial correlation. Another robustness check involves applying the generalized method-of-moments estimator to a dynamic specification of the model (along the lines of Arellano and Bond, 1991), wherein earnings in year $t$ depend on earnings in year $t-1$ :

$$
y_{i t}=\omega y_{i t-1}+X_{i t} B+\sum_{k} D_{k, i t} \delta_{k}+R_{i} \sum_{k} D_{k, i t} \lambda_{k}+\gamma_{t}+\alpha_{i}+\varepsilon_{i t}
$$

The model is estimated using a sample of workers who were laid off from their jobs for an indefinite time period in the early 1990s. Some of these workers were observed to have been recalled by their previous employer prior to 1995. The data set encompasses one year of pre-displacement earnings-corresponding to 1992, 1993, or 1994, depending on the timing of the initial layoff-and nine years of post-reemployment earnings, 1995 to 2003. Thus, the data form a weakly balanced panel set, in which each individual $i$ is observed for ten years, with $t$ taking on the values pre-1995, 1995, 1996, .., 2003. For reasons related to data availability, the annual time intervals are earning years (defined below), rather than calendar years.

The first observable earnings after layoff are for the first, second, or third subsequent year, depending on when the initial layoff occurred. Analogously, the last observable earnings refer to nine to eleven years after the initial layoff. In other words, $k$ goes from 1 to 9 for some individuals, from 2 to 10 for others, and from 3 to 11 for the remainder of the 
sample. As a result, the most reliable estimates of the earnings effects of job loss are for years 3 through 9 after layoff, when all individuals' earnings are observed. Because of very small sample sizes, the coefficients for years one and eleven are never significant and are not presented.

The Jacobson, LaLonde, and Sullivan studies of Pennsylvania workers (1993a, 1993b) demonstrated the empirical importance of the so-called "Ashenfelter dip," whereby earnings begin to decline two to three years prior to layoff, relative to the earnings of workers who remain employed. The current study assumes that the Ashenfelter dip was identical for the permanently and temporarily laid-off workers, conditional on the other variables that enter the model. The empirical evidence presented in Jacobson, LaLonde, and Sullivan (2005) lends some support to this premise. Comparing three groups of displaced workers in Washington State with different community college enrollment patterns after these layoffs occurred, the authors found that their pre-layoff earnings moved in parallel until about four quarters prior to displacement. ${ }^{3}$ Therefore, while not encompassing any pre-layoff reductions in earnings, $\lambda_{k}$ should provide an accurate measure of the relative long-term earnings effects of permanent versus temporary job loss.

Another issue is that longer-term earnings trends (prior to the period of the Ashenfelter dip) may have been different for permanent job losers and temporary job losers. If so, their post-reemployment earnings trajectories may differ for reasons unrelated to their recall status. Previous studies have indicated that considering differences in time trends has a material effect on the results only in some instances. For example, Stevens (1997) found that controlling for worker-specific trends did not significantly alter the findings on the effects of job loss on earnings, while in Jacobson, LaLonde, and Sullivan (1993b), worker-specific trends had different effects on the results (both in direction and significance), depending on the sample studied.

For the Massachusetts data set, the unavailability of earnings data prior to one year

\footnotetext{
${ }^{3}$ Furthermore, the pre-layoff earnings differences between stayers and separators in the Jacobson, LaLonde, and Sullivan Pennsylvania mass-layoff sample were found to be small (see Sullivan and von Wachter 2007).
} 
before the layoff precludes controlling directly for unobservable sources of differences in earnings trends. The study, however, is able to control for factors such as age and education that are associated with differences in earnings trajectories. In addition, information on tenure at the previous job is used to show that pre-displacement earnings gaps between recalled and non-recalled workers did not increase with the duration of employment, as would be expected if recalled workers had experienced higher trend earnings growth prior to layoff. This evidence casts doubt on the likelihood that, subsequent to the initial layoff, recalled workers as a group would have had higher earnings growth than permanently laid-off workers for reasons independent of recall status.

\section{The Massachusetts Data}

For this study, the data on displaced workers were obtained from three administrative sources: federally-funded JTPA assistance programs overseen by the Massachusetts Industrial Services Program (ISP), now known as Commonwealth Corporation (CommCorp); Massachusetts unemployment insurance (UI) claims files; and Massachusetts UI-covered wage records. Observations for individuals were matched via Social Security number by CommCorp. Together, these sources provide a considerable amount of demographic information, along with an earnings history.

\section{A. Overview of the data sources}

Workers displaced from jobs in the early 1990s were eligible to apply for services established under the Economic Dislocation and Worker Assistance Act (EDWAA), a 1988 amendment to Title III of JTPA (Balducchi, Eberts, and O'Leary, 2004). In 1995, the ISP provided the author with administrative records for the 23 dislocated worker assistance centers operating in Massachusetts. These records include data stripped of identifiers for all 20,624 workers who were laid off between January 1991 and September 1994 and were served by JTPA/EDWAA programs in the state. Included is information about each individual's previous job, demographic characteristics, use of reemployment services, and 
(where applicable) initial characteristics of the new job. Of these worker records, 19,009 contained sufficient data to be usable for research purposes.

The early 1990s coincided with a severe recession-induced reduction in Massachusetts employment and a pronounced shift in its composition away from manufacturing and towards services. There were also severe job losses in defense-dependent industries as a result of the end of the Cold War. On net, Massachusetts lost over 300,000 nonfarm jobs between the business cycle peak in 1989 and the trough in 1992, a decrease of about 10 percent. In the aggregate, the state made up about one-third of these net job losses between 1992 and 1994, but manufacturing employment continued to fall. The labor force also fell, as large numbers of workers moved from Massachusetts to other parts of the nation with better economic opportunities. Despite this outmigration, the state's unemployment increased sharply. The overall jobless rate in Massachusetts was only 3.3 percent in 1988, but reached 8.8 percent in 1991 and 1992, and remained above 6 percent until late 1994. ${ }^{4}$

In addition to the dismal condition of the state's economy in the early 1990s, displaced workers who enrolled in JTPA programs in Massachusetts were hampered in their job search as a result of having worked for employers with higher pay scales, but which put less emphasis on developing transferable skills and had a different type of corporate culture than firms that were hiring. For example, in interviews conducted by the author in the mid1990s, worker assistance center personnel noted repeatedly that their clients came from workplaces that had been somewhat insulated from the prevailing pressures for costeffective production and service delivery. Many of the laid-off workers reportedly were unfamiliar with computer applications that were widely used at other workplaces because their former employers had tended to favor developing proprietary software. ${ }^{5}$ Therefore, these workers were viewed as a poor match for the (relatively few) job postings offering a

\footnotetext{
${ }^{4}$ Compared with the downturn in Massachusetts, the national recession of 1990-91 was mild. Payroll employment fell 1.5 million between its 1990 Q2 peak and its 1991 Q3 trough, about 2 percent. The national unemployment rate increased from 5.3 percent in 1989 to 7.5 percent in 1992. For further description of the ISP sample and the Massachusetts economy of the early 1990s, see Kodrzycki (1996).

${ }^{5} \mathrm{~A}$ brief overview of interviews in Massachusetts and nearby states can be found in Kodrzycki (1995).
} 
wage similar to what they had been earning prior to displacement.

The ISP files were cleaned by the author, and then combined with related economic information to enable investigation of the short-term consequences of job loss, as assessed by the duration of joblessness, and by the hourly wage and other job characteristics present immediately upon reemployment (Kodrzycki 1996, 1997). The short-term costs of job loss were substantial. Only one-third of the workers were observed by the ISP to be reemployed within 12 months of layoff. This is far lower than the U.S. aggregate post-2000 job-finding rates estimated by Hall (2005), but it is broadly consistent with the findings of Imbens and Lynch (2006) that business cycles have substantial effects on reemployment probabilities. The average real hourly wage loss for workers finding a new job was equal to nearly 13 percent of their pre-layoff wage, and relatively few reemployed workers were covered by employer-provided medical and pension benefits at their new jobs. Nearly one-half of the sample received job training or general education services under the auspices of JTPA, but such programs did not augment their starting pay, as compared with the starting pay of individuals who received only basic readjustment services, controlling for selection into the supplemental services.

As noted earlier, a key advantage of using the ISP data set to construct the sample is that it is likely to contain records only on displaced workers. By virtue of JTPA/EDWAA requirements, assistance was restricted to individuals who lost their jobs involuntarily in mass layoffs or plant closures, or who had been otherwise laid off and deemed highly unlikely to return to their previous jobs. ${ }^{6}$ Prior studies of job loss have commonly inferred whether a worker had been displaced on the basis of self-reported status or wage record gaps, and thus have likely included some firings for cause, voluntary separations, and elective movements into and out of the labor force. Bowlus and Vilhuber (2002) showed that workers who voluntarily left a distressed firm had higher reemployment wages than workers who stayed with the distressed firm until displacement, even controlling for worker and firm characteristics.

\footnotetext{
${ }^{6}$ Evidence in Office of Inspector General (2000) indicates that the official eligibility standards were likely relaxed as JTPA program funding increased and as the economy improved in the late 1990s.
} 
On the other hand, the ISP data have significant drawbacks, including a reliance on self-reported data on hourly wages and hours worked, and a lack of any data on wages or hours worked beyond the end date of the previous job and the start date of the new job. To obtain more reliable information on past earnings, this study uses Massachusetts unemployment insurance (UI) claimant files, available for each benefit spell beginning or continuing since the third quarter of 1992. UI benefits depend on base period earnings, which are provided as part of the UI records. This base period is intended to capture a year's worth of earnings prior to displacement, although the definition of a base period has changed somewhat over time.7 Since employers report these earnings amounts to the Massachusetts Division of Employment and Training, and these firms were subject to auditing by the state, the amounts used in this data set can be considered far more reliable than any earnings measures constructed by multiplying self-reported hourly pay and hours worked.

The UI files in Massachusetts contain extensive demographic information compared with those in some of the other states that have made their records available to researchers studying job loss. In addition to layoff date, sex, age, and former industry, the data contain information on the worker's tenure with the previous employer, education, number of dependents, and veteran and citizenship status.

Post-displacement earnings through 2003 were obtained from the UI wage records, which were used to determine employer contributions to the state's unemployment insurance system. Employers in covered sectors (representing about 98 percent of total nonfarm employment in Massachusetts) report quarterly payments to each employee on their Massachusetts payroll. Each individual worker who earned wages in a covered sector has an entry by employer, up to eight employers in total. This study uses total earnings from covered employment in Massachusetts. As in other studies based on individual state wage records, self-employment income and earnings from out-of-state employers are not

\footnotetext{
7 Prior to October 1993, the base period was defined as the last 52 weeks of earnings prior to displacement. From October 1993 to October 1994, the base period consisted of the fifth complete quarter prior to displacement through the second complete quarter prior to displacement. After
} 
available.

The study uses the ISP database only where it provides highly relevant but otherwise unavailable information on worker and employer characteristics. First, the ISP data were used to determine whether a worker was recalled. This information is indicated by the code denoting the reason for terminating JTPA services, or by the fact that the name of the new employer is the same as the old employer or is one of its business units. Unfortunately, the ISP data provide no information as to why a worker was recalled. A search of newspaper articles, published during the time period when the employment losses were incurred and the subsequent recalls occurred, indicates that some Massachusetts defense contractors received unexpected new orders, thus causing these firms to increase production and to recall workers. Contemporary newspaper sources from the early to mid-1990s do not provide any evidence on what factors might have motivated the observed recalls made by other types of firms. Second, scores on a reading test administered as part of JTPA basic readjustment services were used as an indicator of transferable human capital. Reading ability and other general skills are typically unobserved by researchers, so having this information enhances the value of this data set. Finally, the information from the ISP data was used to limit the regression analysis to individuals who had been working full-time prior to layoff.

\section{B. Construction of the panel data set}

The panel data ultimately used for estimating earnings results was created from these three administrative sources, matching individuals across the data sets. Beginning with the displaced workers in the ISP data, using their Social Security numbers individuals were matched with their layoff event in the UI claims files. This procedure yielded reliable administrative data on the layoff event, tenure with the previous employer, industry, and earnings in the year prior to displacement. Of the 19,009 unique Social Security numbers

provided by ISP, only 12,091 were found in the UI claims files. Reasons for this discrepancy included the lack of UI records for individuals whose unemployment benefit spell ended

October 1994, the base period consists of the last four complete quarters before displacement. 
before July 1992, or who did not file for UI benefits in Massachusetts. ${ }^{8}$ In addition to matching Social Security numbers, employer names were matched for 9,146 individuals. ${ }^{9}$ This smaller sample formed the basis of this paper's study. From the merger of these two data sets, we have a set of demographic information along with administrative data on job tenure and pre-displacement earnings.

These records were then matched to UI wage record files, which provided the stream of post-displacement quarterly earnings, beginning with fourth quarter of 1994, the first period for which comprehensive data could be retrieved by the state. Hence, there is a period of unknown duration for which we were unable to observe earnings for workers who were reemployed prior to the fourth quarter of 1994.

The quarterly earning observations were deflated using the CPI (base period $=2004$ Q1), and then aggregated into yearly observations in order to match the periodicity of base period earnings in the UI claimant files. ${ }^{10}$ Since the post-displacement earnings series began with the fourth quarter of 1994, an earning year (EY) was defined to be the fourth quarter of the prior calendar year plus the first three quarters of the matching calendar year. Thus, for example, EY1995 encompassed the fourth quarter of 1994 through the third quarter of 1995.

The final step in constructing earnings observations was to assign base period

\footnotetext{
8 Wandner and Stettner (2000) found that, nationally, only about two-thirds of individuals eligible for unemployment benefits actually applied. Administrative reports pertaining to JTPA Title III participants in the early 1990s cited even lower figures (U.S. Department of Labor 1995, 1996). A legitimate reason for not filing is that Massachusetts law calls for deferral of UI benefits while dismissed employees receive severance pay from their previous employer. A previous study by the author indicated that many of the workers in the ISP sample were likely to have been eligible to receive severance benefits (Kodrzycki 1998). In addition, because information technology was less sophisticated in the early 1990s than it is today, some unknown portion of the missing matches for Massachusetts can be attributed to reporting or clerical errors.

9 The ISP data frequently had more than one name for what was obviously the same employer (for example, $A B C, A B C$ Co., $A B C$ Company, $X Y Z$ division of $A B C$ ). We converted employer names to match the conventions in the UI claims data. Some employers contracted out the task of providing information used in the administration of the UI system. In some of these cases, the name of the reporting unit (rather than the employer) was provided to the UI administration, so we were unable to confirm that the ISP was picking up the same layoff event as the UI administration. To err on the conservative side, we omitted these observations from the reported findings. However, very similar findings were obtained on the basis of the larger sample, not restricted to individuals with matching employer names in the ISP and UI claimant data sets.
} 
earnings for each individual to a single earning year. The determination of this year was made according to when these workers earned the majority of their base-period pay. Prelayoff earnings were then deflated using the CPI for the appropriate earning year.

The end product is a person-year panel data set containing 10 annual observations for each of the 9,146 individuals whose layoffs in the early 1990s prompted enrollment in JTPA dislocated worker programs and receipt of UI benefits in Massachusetts. For each individual, the data set contains one pre-displacement earning year observation (either EY 1992, EY 1993, or EY 1994), as well as (nonzero) Massachusetts earnings for up to nine postdisplacement earning years (EY 1995 to EY 2003).

\section{Workforce attachment}

Not surprisingly, the fraction of the sample working in Massachusetts declined over time. Non-recalled workers were somewhat less likely than recalled workers to have positive earnings in Massachusetts after EY 1994. For example, 82.0 percent of non-recalled workers were employed in-state two years after their initial layoff, compared with 86.4 percent of the recalled workers. Over time, the shares of the re-employed fell for both groups - those who found jobs with new employers as well as those who were recalledalbeit slightly more for the non-recalled (Figure 1). Ten years after layoff, the participation rates were 65.2 percent for the permanently laid-off workers and 71.8 percent for the temporarily laid-off workers.

Some of the growing attrition was due simply to withdrawals from the Massachusetts workforce as a result of retirement and outmigration. However, other potential reasons for not having earnings in a covered sector in Massachusetts during a given year include an extended unemployment spell (perhaps as a consequence of a subsequent layoff), employment in a sector not covered by UI requirements, selfemployment, permanent or temporary withdrawal from the labor force for reasons other than reaching retirement age, and commuting to employment outside the state. It is not

\footnotetext{
${ }^{10}$ Another reason to use annualized observations is that the quarterly data exhibit marked seasonality.
} 
possible to determine which of these various possible factors is responsible for a given quarter of zero earnings.

In order to minimize faulty interpretations of quarterly data showing zero earnings, the study follows Jacobson, LaLonde, and Sullivan (1993a, 1993b, 2005) in restricting the analysis to workers who show a high degree of attachment to the state labor force. Specifically, the sample includes only those persons who had positive Massachusetts earnings in each year from EY 1995 to EY 2003. Essentially, this attachment test eliminates from the estimation any individual who permanently moved out of state or who permanently stopped participating in the labor market. The result is a sample of active, attached labor market participants across the full observation period.

The attachment test reduces the sample from 9,146 individuals to 3,753 individuals. The fact that Massachusetts is a small state, together with the fact that the sample contains a sizeable proportion of workers nearing typical retirement age, tends to increase the likelihood that workers may have been dropped from the sample as a result of applying the labor force attachment test. On the other hand, in the late 1990s the Massachusetts economy was unusually strong, a condition which tends to boost labor force participation and employment. In any case, the elimination of over half the sample as a result of applying the attachment test is roughly consistent with Jacobson, LaLonde, and Sullivan's experiences using data from Pennsylvania and Washington State. Similar percentages of recalled and non-recalled workers pass the labor force attachment test. Recalls are 4.3 percent of the sample before applying the labor force attachment test and 4.4 percent after making this restriction.

The recall percentages for this sample are much smaller than encountered in the previous literature on job recalls, which focused on the 1970s and 1980s when employers (especially those in the manufacturing sector) commonly used temporary layoffs to adjust to downturns in demand (for example, Corak 1996, Katz and Meyer 1990). The general shift away from temporary layoffs over time corroborates the study's assumption that the sampled Massachusetts employers and employees likely viewed the layoffs of the early 1990s as permanent. Moreover, even if the displaced employees had initially overestimated 
the likelihood of being recalled by their former employer, the job search counseling they received as part of JTPA services would have served to "put [them] in touch with the realities of the job market" (Anderson 1992, p. 110). ${ }^{11}$ For these reasons (as well as because JTPA services were limited to individuals who were highly unlikely to be recalled by their former employers), the study is based on the premise that recalls were unforeseen by either the former employees or their employers.

\section{Comparing displaced workers in Massachusetts to national samples}

A summary of the characteristics of the workers in the original Massachusetts ISP data set, the full matched sample, and the portion of the matched sample that met the labor force attachment test are shown in the first three columns of Table 1. Men account for just over one-half of each of these samples, and whites account for nearly 90 percent. Over six in ten workers in the sample had been employed in manufacturing, and a similar share either did not have a high school diploma or had a high school diploma but no college education. The average wage prior to displacement was about \$13 per hour. The bulk of the workers were between the ages of 35 and 54 at the time of initial layoff, but there are some noticeable differences across the different versions of the sample. Younger workers (those under the age of 35) comprise somewhat smaller shares of the matched samples than in the original ISP data set, perhaps because they were more likely to have moved out of Massachusetts in search of new labor market opportunities since losing their job than was the case for middleaged workers. In the full matched sample (column 2), close to 18 percent of the displaced workers were 55 years of age or older at the time of layoff. Probably due to high retirement rates, a larger than average share of these older workers failed the labor attachment test, so only about 11 percent of the regression sample members were at least 55 years old (column 3).

Columns (4) and (5) compare the profiles of JTPA/EDWAA enrollees in Massachusetts

${ }^{11}$ It is further assumed that all workers who were offered reemployment through recalls accepted these offers. A study issued by the U.S. Department of Labor Employment and Training Administration (1992) confirms that, apart from the retail trade sector, very high shares of workers 
with the national averages in program years (PY) 1993 and 1994, which comprise the first available observations after the enactment of national reporting requirements for these programs. ${ }^{12}$ The patterns are similar, except for some underlying differences in the demographic composition of the workforce and in pay scales. In Massachusetts, compared to the nation as a whole, greater shares of participants were white and at least 45 years old. Perhaps because of the greater prevalence of older cohorts, a greater share of Massachusetts participants had not completed high school, and the average reading ability in Massachusetts was about three-quarters of a grade-level lower than the national average. Hourly earnings were higher for Massachusetts enrollees at both the old and new jobs, but the mean and median percent differences in pay between the new and old jobs were similar to those found across the United States.

Comparing the characteristics of JTPA/EDWAA enrollees with those in the biennial Displaced Worker Survey supplements to the Current Population Survey (columns 6 and 7), ${ }^{13}$ we see that across the nation, females, non-whites, and older workers accounted for larger fractions of JTPA/EDWAA participants than of CPS displaced workers. Finally, greater shares of JTPA/EDWAA participants had completed only high school; smaller shares were high-school dropouts or had some college education. The breakdown by sex agrees with the observations of worker assistance center personnel mentioned during interviews with the author conducted during the mid-1990s. These officials noted that women who had lost their jobs appeared more willing to seek reemployment assistance than male job-losers.

As noted, over 60 percent the Massachusetts ISP sample had been employed in manufacturing. This figure is far higher than the 31 percent and 22 percent shares in the 1994

accepted recall offers in the late 1980s, despite the very low unemployment rate.

${ }^{12}$ Thanks to Randall Eberts and staff of the W.E. Upjohn Institute for providing JTPA data collected through the Standardized Program Information Report. Data refer to participants who terminated in the indicated program years. Comparisons along further dimensions may be found in the PY 94 SPIR Data Book: Massachusetts (Social Policy Research Associates 1996), kindly provided by Ernesto Liang of the U.S. Department of Labor Employment and Training Association and Richard W. West of Social Policy Research Associates.

13 To meet the CPS definition, the surveyed individual must have been employed at a plant or company that closed down, had insufficient work, or abolished his or her position or shift within the previous three-year period. 
and 1996 CPS supplements. Unfortunately, comparable data on industry composition do not exist for the national JTPA/EDWAA population. The disproportionate representation of manufacturing workers in the Massachusetts ISP data is probably attributable in part to the state's steep job losses in this traditional industrial sector during the early 1990s. This heavy concentration also was probably due to the national JTPA/EDWAA statutory and budgetary mandate to provide a "rapid response" in the event of plant closures and mass layoffs (U.S. Department of Labor 1996).

Not surprisingly, in light of the severe economic downturn in Massachusetts and the JTPA's focus on helping workers deemed unlikely to find new jobs comparable to the ones they had lost, the Massachusetts ISP workers experienced larger median earnings losses (24 to 28 percent) than did displaced workers included in the CPS (8 to 14 percent). A large disparity exists even when the respective samples are restricted to former manufacturing workers.

In summary, the Massachusetts sample appears to be fairly representative of the national population served by JTPA dislocated worker programs in the mid-1990s. However, compared with displaced workers as defined by the CPS, Massachusetts JTPA Title III participants were much more concentrated in manufacturing, a sector with structurally declining employment and skill requirements that differed from those in the rest of the economy. The job searches of these enrollees coincided with a period in which industries such as software, telecommunications, and medical care were becoming increasingly important in Massachusetts.

\section{E. Selection issues}

Table 2 compares the pre-layoff characteristics and earnings profiles of the 3,581 highly attached, permanently displaced workers and the 172 highly attached recalled workers. The sample of recalled workers is disproportionately male, 74 percent, as compared with only 53 percent in the full sample. In addition, worker recalls were more likely to have occurred in manufacturing.

Otherwise, the differences in demographics and skills between the two sets of workers 
are minor. The recalled workers were slightly younger and, on average, had one year less of job tenure. They were more likely to have finished high school, but less likely to have finished four years of college. The two groups had the same average raw score (8.7 on a scale of 1 to 13) on the reading test administered by the worker assistance centers. Judged by comparing the ISP data with the information on Massachusetts enrollees compiled under national reporting requirements (Social Policy Research Associates 1996), this raw score corresponds to just under a tenth-grade reading ability,

Prior to displacement, the workers who lost their jobs permanently had somewhat lower average annual earnings $(\$ 35,928)$ than the workers who were recalled $(\$ 37,068)$, a difference of $\$ 1,140$. Regressions were used to test whether unobservable attributes accounted for the earnings premium of recalled workers (Table 3). The explanatory variables included demographic controls (age, sex, education, number of dependents, citizenship status, veteran status) and characteristics of the previous job (length of job tenure, whether or not the employer was a manufacturer, and layoff quarter). The coefficients for worker and job characteristics followed the expected patterns, and most were highly significant. By contrast, future recall status does not help to explain pre-layoff annual earnings; its coefficient is both small (-338) and insignificant (column 1). This regression result indicates that their prior jobs, earnings differences between recalled and permanently displaced workers can be explained on the basis of observable characteristics at the time they were employed, and not by unobservables that are correlated with post-displacement recall status.

Additional versions of this regression were estimated with recall status interacted with other explanatory variables. The only specification that yielded notable results was one that interacted recall status with job tenure (column 2). Interacted with tenure and tenure squared, the coefficients on recall status were insignificant. This result suggests that past earnings growth per year of tenure was identical for recalled and non-recalled workers, given other factors such as age cohort, education, and industry. This finding serves to dispel concerns about individual-specific earnings trends. However, in this specification, the coefficient on the recall dummy was significant at the 10-percent level and negative, indicating that firms re-hired workers who, on average, had been earning less than the 
regression equation indicates was the norm for workers with comparable skills and employment experience. When employer controls were included for firms that had at least 20 employees in the sample, however, the coefficient on the recall dummy lost significance, while the coefficients on the recall-tenure interaction terms remained insignificantly different from zero (column 3).

The last two columns show the results of similar regressions for the sub-sample of former manufacturing workers. Some of the effects of individual attributes (chiefly veteran status and age between 60 and 65) differ from those in the larger sample. However, the conclusions on the relationship between earnings and recall status are similar: controlling for observable worker and job characteristics, manufacturing firms did not recall workers who had been earning more pre-layoff (column 4), or who had experienced steeper gains in earnings per year of tenure with the company (columns 5 and 6) than other laid-off workers in the sample. Indeed, the evidence in columns 5 and 6 indicates that recalled workers were earning less than would be expected, based on a regression equation using observable characteristics. For this reason, the regression evidence presented below might understate the earnings losses associated with permanent displacement from manufacturing jobs.

\section{Results on Long-Term Post-Layoff Earnings Consequences}

Table 4 shows average earnings in the year prior to displacement and two to ten years after displacement, for permanent separators and for recalled workers. The results are reported for both the full sample and the manufacturing subsample. Also shown are the median earnings replacement rates (post-displacement earnings relative to pre-displacement earnings) for these same years and samples. Figures 2 and 3 depict the same average earnings data in graphical form, and also indicate the overall average earnings in Massachusetts for the corresponding calendar period. ${ }^{14}$

\footnotetext{
${ }^{14}$ Take, for example, the observation corresponding to four years after displacement. This corresponds to earning year 1996 for 46 percent of the sample, earning year 1997 for 53 percent of the sample, and earning year 1998 for the remaining 1 percent. Earnings for all workers are taken from the Bureau of Labor Statistics Quarterly Census of Employment and Wages.
} 
The raw data highlight the severe and lasting earnings reductions following a layoff relative to these workers' pre-layoff situation. Two years after displacement, the average earnings of permanent separators who found new jobs were 38 percent less than the average earnings of this group prior to displacement. Their earnings remained depressed for a lengthy period, and did not surpass their pre-layoff level until eight years after the layoff.

The earnings reductions also were sizeable when measured against average worker pay in Massachusetts. Prior to displacement, the workers in the sample had been earning 8 percent less than the state average; two years later, this disparity was 44 percent. Permanently displaced workers saw greater-than-average earnings gains in years 3 through 8, but somewhat greater-than-average earnings erosion in years 9 and 10, when the Massachusetts economy was in recession. Thus, at the end of the ten-year period, permanently displaced workers were earning 25 percent less than the statewide average. The magnitude of these earnings losses relative to the state average are roughly in line with the findings on mass-layoff separators versus stayers in Jacobson, LaLonde, and Sullivan (1993a, 1993b) and Sullivan and von Wachter (2007).

\section{A. Comparisons to unexpectedly recalled workers}

The earnings outcomes for the recalled workers showed some similarities and some differences from those of the permanently laid-off group. The key similarity is that recalled workers also suffered a substantial yearly earnings loss in the short term. Two years after displacement, the median earnings replacement rate for recalled workers was 74 percentbetter than the 62 percent rate for permanently displaced workers, but still considerably below full earnings recovery. This earnings loss for recalled workers suggests that the demand shocks incurred by their employers resulted in a continuing reduction in worker hours or possibly, as found in Devereux (2005), in the wage rate.

Recalled workers maintained a much larger earnings advantage over non-recalled workers in the decade following recall than they had in the year before displacement. The average earnings gap over the entire post-displacement time period was about $\$ 4,000$. This is 3.5 times as large as the pre-displacement gap between the two groups. 
The size of the earnings disparity between recalled and non-recalled workers changed over time and appeared to vary with overall labor market conditions. The earnings difference was largest three years after layoff, at $0.24 \log$ point, narrowing to a range of 0.15 to $0.17 \log$ point in years 5 through 9. At the end of the sample period, the recession beginning in early 2001 had greater earnings consequences for permanently displaced workers than for recalled workers who continued to work in Massachusetts. The year-10 earnings gap rose to nearly $\$ 5,500$, equivalent to 0.21 log point.

The consequences of a permanent layoff were somewhat greater for the sample of workers employed in manufacturing. The median manufacturing worker who was recalled finally surpassed his or her prior annual earnings seven years after the layoff. In year 7, the median manufacturing worker who was permanently displaced was still earning about 9 percent less than before the job loss, and never surpassed the previous annual earnings during the sample period.

The disparities in earnings between the recalled and non-recalled workers do not appear to be the result of differences in post-reemployment job security, at least to the extent that any such difference can be detected in quarterly earnings records. Both the average frequency and the average duration of nonemployment in earnings years 1995 to 2003 were similar for the permanently displaced and the recalled workers (conditional on high labor force attachment). Both groups experienced an average of three intervals of zero earnings from Massachusetts payroll employment during these years. Furthermore, for both groups, the average duration of these intervals was one and a half quarters. These findings suggest that, on the whole, their post-layoff earnings differences were the result of differences in wage rates and hours worked, rather than being attributable to a different incidence of unemployment spells or to more frequent temporary withdrawals from the Massachusetts labor force.

\section{B. Regression analysis}

Table 5 shows the key regression results with the fixed-effects specification (see equation 2), based on various sets of controls. The entries in this table are the coefficients on 
elapsed time interacted with the recall dummy, which indicate the natural log earnings advantage of recalled individuals relative to non-recalled individuals in each year following the initial layoff, conditional on the other variables. The top panel shows results for the full sample, while the bottom panel is for workers formerly employed in manufacturing.

The results of the specification shown in the first column includes as explanatory variables indicators for the number of years since the initial layoff, the years since the layoff interacted with the recall dummy, and earnings year dummies, but no individual characteristics, with the exception of sex. Recall caused workers to earn about 0.20 log point more in years 2 and 3, and $0.16 \log$ point more in year 4, relative to comparable workers who were permanently displaced. The recall advantage remained substantial through the decade following the initial layoff. It was $0.14 \log$ points in year 8, for example, and it widened slightly to $0.17 \log$ point in year 10 . For the most part, these causal effects of a recall are slightly larger than the raw numbers reported in Table 4.

Adding controls for age, tenure at the previous job, and education increases the model's explanatory power. The tenure and education variables are interacted with age group, allowing age-earnings profiles to be different for workers with different degrees of attachment to their previous employer and with different education levels. The effects of the individual attributes are in line with expectations based on previous findings in the literature. As indicated in Appendix Table 1, for workers with average job tenure and average education levels, earnings peak sometime in the 45-to-55-year-old age bracket and fall sharply after age 60. A tenure of over ten years in the pre-layoff job has negative consequences for the level of earnings in the new job, holding other factors constant. College attendees and graduates earn more than high-school graduates in all age categories. Highschool dropouts earn less than high-school graduates, but this difference is not statistically significant.

Despite their significance in explaining earnings outcomes, the standard human capital measures reduce the estimates of the average benefits of a job recall only very slightly (Table 5, column 2). Even ten years after the layoff, a recall caused these workers to earn 0.14 $\log$ point more than if they had been permanently displaced. 
The reading test score, the final independent variable, provides a measure of ability that previous studies on displaced workers have not been able to include. It enters positively and is found to have especially large effects on earnings for workers aged 60 and older (Appendix Table 1), but it has very little effect on the coefficients for the recall terms and has only marginal effects on statistical inferences (Table 5, column 3). Even after controlling for the reading score, the hypothesis that a job recall has a significant effect on earnings ten years later can be accepted with 94-percent confidence.

For workers laid off from manufacturing jobs, the consequences of a permanent versus a temporary layoff are estimated to be somewhat larger. In the specification without human capital controls, a job recall leads to earnings that are higher by 0.19 log point in years 4 and 8 , and by $0.24 \log$ point in year 10. With the full set of controls, these estimates are $0.17 \log$ point in year $4,0.15$ in year 8 , and 0.19 in year 10 . The recall term is statistically significantly different from zero at conventional levels in most years.

Table 6 compares these regression findings with those in the Pennsylvania analysis of Jacobson, LaLonde, and Sullivan (1993a, 1993b), as updated by Sullivan and von Wachter. In all three post-layoff periods shown-one to two years, three to six years, and seven to eleven years after displacement-the annual percentage earnings losses associated with a layoff are just under one-half those found by Jacobson, LaLonde, and Sullivan. Two possible explanations may account for these disparities. First, as noted in the introduction, the smaller earnings losses in the current study may be due to the reduced selection bias associated with using recalled workers rather than the never-displaced workers as the reference group. Alternatively, the smaller earnings losses may be the consequence of studying a different sample, in which the costs of labor demand shocks were distributed differently between those who were permanently laid off and those who continued to work for the firm. Under this interpretation, the recalled Massachusetts workers and their (unobserved) nondisplaced co-workers were similar in that they both sustained earnings losses associated with their employer's distressed condition, while in the Pennsylvania sample pertaining to job losses in the early to mid-1980s, the burden of the demand shock was felt primarily by those who were laid off. Further research using different samples is 
necessary to determine which of these two explanations is more compelling.

\section{Robustness checks}

The standard errors reported in Table 5 are adjusted for heteroskedasticity and for unrestricted autocorrelation within individual worker histories. However, the estimated residuals from the fixed-effects specification turn out to be autocorrelated. The typical procedure for eliminating autocorrelated errors is to estimate the model using quasi firstdifferenced data. This method was tried for the data used in this study, but it yielded implausibly large standard errors for the recall term, indicating that the sample does not provide enough variation within individual observations of recalled versus non-recalled workers to enable meaningful hypothesis testing under this specification.

Therefore, as a robustness test, equation (1) was estimated by GLS using a random effects specification, with and without a correction for autocorrelation. ${ }^{15}$ In this case, $\alpha_{\mathrm{i}}$ is assumed to be uncorrelated with the independent variables, and coefficient estimates are based on variations both within and across individuals. ${ }^{16}$

The results of the random effects estimation are shown in Table 7. For the most part, the effects of a job recall are only slightly smaller than those estimated by using a fixed effects estimation method. Also, most of the coefficient estimates change very little after correcting for first-order autocorrelation. However, the estimated costs of job loss become somewhat smaller in the longer term as more controls are added. For example, in the specification with a correction for autocorrelation, the estimated coefficient for the recall term in year 10 is 0.14 with minimal controls, and 0.11 with the full set of controls. For the manufacturing sample, the comparable coefficients are 0.21 and 0.16 , respectively.

The second robustness check involved a dynamic specification (equation 2). This model was estimated using the GMM techniques developed by Arellano and Bond (1991)

\footnotetext{
${ }^{15}$ The Hausman test for fixed effects versus random effects was indeterminate.

16 To maximize usable observations when correcting for autocorrelation, it is assumed that individuals for whom earnings are observed in 1992 or 1993 would have had the same earnings had they been observed in 1994. The model was estimated using these adjusted observations for earning years 1994 to 2003.
} 
and Arellano and Bover (1995), as summarized in Roodman (2006). The data are transformed by taking forward orthogonal deviations (that is, subtracting the average of all available future observations). One-period lagged earnings are instrumented by lags of two periods or longer (or by zero where these lagged terms are unavailable).

The dynamic panel specification provides a more stringent test of the effects upon an individual's future earnings of a permanent layoff versus a temporary layoff. The coefficients for the recall term indicate the added benefit of a recall in period $t$, given the individual's earnings in $t-1$. The estimated coefficients are consistently significantly different from zero only in the first several years following displacement (Table 8). For example, using the full sample and the full set of controls, a recall causes earnings to be 0.20 log point higher in year 2 and $0.11 \mathrm{log}$ point higher in year 3. The estimated coefficients for years 4 through 10 are positive (albeit insignificant), suggesting that the earnings of permanently laid off workers were lower, relative to their recalled peers, during these years than would have been expected, as based on their measurable human capital and their post-layoff earnings history. For the manufacturing-only sample, the year 2 and year 3 post-recall effects are similar to the results for the full sample. In addition, manufacturing workers were found to benefit significantly from recall in year 10 . They earned 0.10 to $0.12 \log$ point more than their non-recalled peers, even controlling for their earnings progress during the late 1990s boom. These coefficients are significant at the 10-percent level.

\section{Heterogeneity across subgroups}

The literature indicates that permanent job loss is particularly costly for workers with high firm-specific human capital relative to general human capital. Table 9 shows the results of testing whether a job recall has a differential positive effect for older workers, lesseducated workers, and long-tenured workers. The specification used is a simpler version of equation (1), in which the effects of job loss and recall are measured for three periods: one to three years, between four and nine years, and ten or more years after displacement. The model is estimated using random effects. The most striking findings are that the earnings outcomes of less-educated workers are particularly dependent on whether or not the job loss 
is permanent, and that this effect is long-lasting.

As shown in column 1, being more than 45 years old at the time of displacement has a negative effect ( $0.15 \log$ point) on future earnings. Job recalls have a differential positive effect on this group of older workers, but the results are not statistically significant. The second column shows the effects of allowing the recall earnings effects to vary by educational attainment (but not age). The results indicate that a job recall has sizeable positive effects on workers with a high-school education or less (column 2). Being recalled rather than permanently displaced raises earnings $0.27 \log$ point in years 1 to $3,0.17 \log$ point in years 4 through 9, and 0.23 log point in years 10 and 11. Finally, column 3 shows positive and increasing coefficients for the variable combining recall with length of tenure and elapsed time since displacement. These findings indicate that long-tenured workers who are recalled after a layoff have higher earnings growth than long-tenured workers who are permanently laid off.

\section{Further Considerations on Using Recalled Workers as the Comparison Group}

The premise of this study is that job recalls in Massachusetts during the early 1990s were not systematically related to any omitted worker or employer characteristics that significantly affected future earnings levels or growth. If this assumption is not met, the coefficients on the recall dummies reflect these factors in addition to the pure effects of the recall. Another concern is that some recalled workers might have had only brief reemployment with their former employers, and were in fact unemployed or employed by another firm when observed again in fourth quarter 1994. In this case, their decreased earnings would reflect the effects of subsequent layoffs, as opposed to the terms on which they were recalled by their previous employer, and the coefficients on the recall dummies would tend to understate the earnings costs associated with permanent versus temporary layoff. This section addresses these hypotheses about possible coefficient bias or misinterpretation. 


\section{A. How Unexpected Were Job Recalls?}

As noted already, recalls were rare in this sample, and later recall status was not significant in explaining a displaced worker's previous earnings, conditional on factors such as age, sex, race, education, job tenure, reading test score, and industry. In other words, those workers who were later recalled could not be identified as having attained higher pay because they possessed a given set of unobserved, pre-existing characteristics.

Furthermore, job recalls were not highly correlated with the identity of the former employer. Recalls were widely distributed across firms and were generally few relative to firm size (Table 10). Roughly one-third of the recalled workers returned to employers who did not recall any other workers in the sample. More than half returned to employers who re-hired four or fewer workers. Of the five companies that recalled nine or more workers, three had recall rates of 10 percent or less (computed relative to the number of displaced workers who enrolled in worker assistance programs). Only the remaining two companies had high recall rates (one recalled 10 of its 15 workers, and the other recalled 14 of its 37 workers), but together these firms account for only 14 percent of the overall recalls in the sample.

More generally, the literature on expected versus actual recalls emphasizes that job losers initially form poor estimates of their likelihood of returning to their previous employers. Katz and Meyer (1990) find that laid-off workers first overestimate their

probability of recall, and then adjust their estimates downward over time. Fallick and Ryu (2007) show that expectations of a recall have only a small effect on laid-off workers' job search activity, a result that is consistent with the view that workers are poorly informed about their prospects of being rehired by their former employer. Anderson (1992) finds that an important role of job search assistance programs is to help workers assess correctly and revise downward their recall prospects. In her sample of newly qualified UI claimants in New Jersey in the late 1980s, workers' estimates of recall probability are generally revised sufficiently after one quarter so as no longer to affect their probability of taking a new job. Those receiving counseling about job market conditions revised their recall probabilities more quickly than those who did not. Although job losers on the whole underestimate the 
permanence of this displacement, firms also recall some workers who do not expect to be hired back (Corak 1996).

Taken together, these findings suggest that the Massachusetts workers and employers in the sample were unlikely to detect in advance which layoffs would be only temporary. Furthermore, they would have observed that the economy's depressed condition served to weaken any connection between favorable employee or employer attributes and the likelihood of reemployment.

\section{B. Were Job Recalls Mostly Temporary?}

As noted in section II.A., which discusses the data sources, administrative information from the JTPA/EDWAA programs overseen by the ISP was used to determine which Massachusetts workers were recalled. This procedure leaves open the question of whether, as of the beginning of the UI wage records in fourth quarter 1994, these recalled workers remained employed by the same firms that had laid them off. Unfortunately, this question cannot be answered precisely. The available data from the UI wage records contain only employer identification numbers (but not employer names), while the available data from the UI claims contain employer names (but not identification numbers). A further complication, mentioned by other researchers who have used administrative records, is that employer identification numbers can change as companies reorganize or merge, or if they shift payroll processing or other recordkeeping responsibilities to an outside vendor. Thus, a change in an employer identification number associated with a given worker can be due to other factors besides a job change. These data limitations notwithstanding, information on multiple recalls by the same employer can still be used to cast serious doubt on the possibility that recalled workers' earnings losses were largely the consequence of either a subsequent job loss or employment under contingent status (such as through a temporary help agency or as an independent contractor).

As indicated in Table 10, twenty of the 1,033 firms in the sample were recorded as having recalled two or more employees. These firms accounted for 113 of the total 172 recalls in the sample. Records for these individuals were examined to determine the degree 
of employer identifier number matches among former co-workers in fourth quarter 1994. A two-part test was used to provide strong evidence that a recalled employee continued to work for his or her recalling employer. First, all recalled employees who had been laid off by a given employer had to have the same primary employer identification number in fourth quarter 1994. Second, no additional recalled workers had the same identification number for their primary employer in that period. This is a particularly stringent test in Massachusetts, where employers may elect to use different identification numbers for individual establishments.

Table 11 compares the change in earnings between the pre-displacement period and earning year 1995 for the 41 recalled individuals (from seven firms) who were "strictly confirmed" as remaining with the previous employer, against the earnings of the 364 permanently laid-off employees of these same companies, as well as against the comparable figures for the full regression sample. "Strictly confirmed" recalled workers earned 25 percent less in earning year 1995 than in the year prior to displacement (adjusted for inflation). Their co-workers who were permanently laid off suffered an average earnings loss of 38 percent. ${ }^{17}$ This 13 percentage-point gap between permanently laid off and recalled workers' earnings losses compares with a 9 percentage point gap in the regression sample as a whole. ${ }^{18}$

Taken together, these results using "strictly confirmed" recalls suggest that the measured post-recall earnings losses in the full sample are not merely an artifact of very short-term reemployment followed by unobserved layoffs. Furthermore, while the estimated costs of permanent layoffs would likely have been somewhat greater if measured against a reference group who returned to their previous employer for at least some prespecified number of years, these costs would still be considerably smaller than if measured relative to workers whose employers provided them with uninterrupted employment.

\footnotetext{
17 For six of the seven companies represented, the average real earnings of recalled workers were lower in earning year 1995 than prior to displacement, and the percentage drop was greater than for non-recalled workers.

${ }^{18}$ Repeating the regressions shown in Table 5 using the reduced sample of workers who had been employed at firms with strictly confirmed recalls increases the year 2 earnings increase from layoff to between .28 and .31 log point in the all-industry case and to between .23 and .27 log point in the manufacturing-only case.
} 


\section{Summary and Discussion}

This paper has examined the long-term earnings consequences of layoffs that occurred in Massachusetts during the early 1990s, using a sample of experienced workers who enrolled in federally-funded assistance programs under Title III of the Job Training Partnership Act, and who remained strongly attached to the state's workforce through the early 2000s. Approximately three-fifths of these workers had been employed in the manufacturing sector at the time of displacement, and almost all of the layoffs occurred in calendar years 1992 and 1993.

The main research focus was to compare the earnings of individuals who were permanently laid off with those of otherwise similar individuals who were unexpectedly recalled by their former employers shortly after the initial layoff. The differential between the earnings of these two groups was especially sizeable in the short term (two to three years following displacement), but it remained noticeable a decade later, even after adjusting for sex, age, education, tenure at the previous employer, and reading ability at the time of layoff. These results demonstrate that the available assistance programs for displaced workers were insufficient to offset the losses of specific human capital and wage premia that accrued from working in particular jobs or sectors. The study also found that experiencing a permanent layoff was particularly costly for workers whose formal education did not extend beyond high school. A policy prescription might therefore be to explore the efficacy of providing stronger incentives for less-educated workers to pursue further education and training while employed, as opposed to concentrating only on post-displacement interventions.

This study provides insights into how results pertaining to job displacement may be affected by the choice of the control group. Using workers who were initially laid off but then unexpectedly recalled resulted in substantially lower estimates of the costs of job loss than doing a simple "before and after" calculation of displaced workers' earnings. The estimates also were lower than would be found by applying a difference-in-differences 
approach that compares displaced workers to the average of all employed workers. In the data set developed in this paper, the choice of the comparison group was much more important in the measurement of short-run earnings losses than was controlling for the attributes (age, education, and the like) of the individuals in the sample. Controls for individual characteristics mattered somewhat more for measuring the long-term causal earnings effects of layoffs than these did for measuring short-term effects.

The study documents the fact that recalled workers also suffered earnings erosion, a finding which suggests that their employers faced economic pressures that persisted in the latter half of the 1990s. Although the Massachusetts economy experienced unusually high growth during this time period, much of this strength was attributable to services industries, rather than to the manufacturing sectors that recalled these employees. Since Jacobson, LaLonde, and Sullivan found less negative results for survivors of mass layoffs in their study of the Pennsylvania sample from the 1980s, future research might address the determinants of earnings at firms that initiate large layoffs, and explore whether these relationships have changed over time. As employers' decisions concerning terminations have become less correlated with easily observable characteristics of specific workers (such as their seniority or union status), it may turn out that remaining employees have suffered negative earnings spillovers as a consequence of a firm's reductions in its labor force.

The research found that workers who were displaced in the early 1990s were disproportionately affected by the economic slump of the early 2000s. To test whether this observed relationship is idiosyncratic to a particular business cycle or location, one would need access to information about laid-off workers in different economic environments, as will be possible through the Census LEHD project, which combines matched employeeemployer data from an increasing number of participating states. If further research bears out this paper's preliminary findings that recessions impose earnings costs on past job losers who remain in the labor force, this would serve to augment the macroeconomic welfare costs of business cycles identified in Krebs (2007). In this case, an even stronger argument could be made for pursuing policies that foster steady growth in the macroeconomy, perhaps in combination with assisting displaced workers to relocate to areas where the local economy is 
relatively strong.

In summary, the evidence from this study lends credence to the view that, as a group, displaced workers suffer indefinite earnings losses following a layoff, even if they manage to remain fairly steadily employed. The typical worker who was laid off and then reemployed at a different job continued to earn less than the income earned at the predisplacement job until the eighth year following the layoff. Furthermore, in this sample, the earnings gap between permanently laid-off workers and Massachusetts employees on average was far greater in the early 2000s than it had been before the displacements occurred. 


\section{References}

Abowd, John M., Francis Kramarz, and David N. Margolis. 1999. "High Wage Workers and High Wage Firms." Econometrica, 67, no. 2 (March), pp. 251-333.

Abowd, John M., Paul Lengermann, and Kevin McKinney. 2002. "The Measurement of Human Capital in the U.S. Economy." U.S. Census Bureau LEHD Technical Paper No. TP2002-09.

Anderson, Patricia M. 1992. "Time-Varying Effects of Recall Expectation, a Reemployment Bonus, and Job Counseling on Unemployment Durations." Journal of Labor Economics, 10, no. 1 (January), pp. 99-115.

Arellano, M. and S. Bond. 1991. "Some Tests of Specification for Panel Data: Monte Carlo Evidence and An Application to Employment Equations." Review of Economic Studies, 58, pp. 277-97.

Arellano, M. and O. Bover. 1995. "Another Look at the Instrumental Variables Estimation of Error-Components Models." Journal of Econometrics, 68, pp. 29-51.

Balducchi, David E., Randall W. Eberts, and Christopher J. O'Leary, eds. 2004. Labor Exchange Policy in the United States. Kalamazoo, MI: W.E. Upjohn Institute for Employment Research.

Bewley, Truman F. 1995. “A Depressed Labor Market as Explained by Participants." American Economic Review, 85, no. 2 (May), pp. 250-254.

Bowlus, Audra and Lars Vilhuber. 2002. "Displaced Workers, Early Leavers, and Reemployment Wages.” U.S. Census Bureau Technical Paper no. TP-2002-18 (November).

Carneiro, Anabela and Pedro Portugal. 2003. “Earnings Losses of Displaced Workers: Evidence from a Matched Employer-Employee Dataset." Working paper.

Corak, Miles. 1996. "Unemployment Insurance, Temporary Layoffs, and Recall Expectations." The Canadian Journal of Economics, 29, Special Issue: Part 1 (April), pp. S1-S7.

Devereux, Paul J. 2005. “Do Employers Provide Insurance against Low Frequency Shocks? Industry Employment and Industry Wages." Journal of Labor Economics, 23, no. 2 (April), pp. 313-340.

Eliason, Marcus and Donald Storrie. 2006. “Lasting or Latent Scars: Swedish Evidence on the Long-Term Effects of Job Displacement." Journal of Labor Economics, 24, no. 4, pp. 831-856. 
Fallick, Bruce C. 1996. "A Review of the Recent Empirical Literature on Displaced Workers.” Industrial and Labor Relations Review, 50, no. 1 (October), pp. 5-16.

Fallick, Bruce and Keunkwan Ryu. 2007. "The Recall and New Job Search of Laid-Off Workers: A Bivariate Proportional Hazard Model with Unspecified Heterogeneity." The Review of Economics and Statistics, 89, no. 2, pp. 313-323.

Farber, Henry S. 2003. “Job Loss in the United States, 1981-2001." NBER Working Paper 9707 (May).

Hall, Robert E. 2005. “Employment Efficiency and Sticky Wages: Evidence from Flows in the Labor Market." Review of Economics and Statistics, 87, no. 3 (August), pp. 397-407.

Huttunen, Kristiina, Jarle Møen, and Kjell G. Salvanes. 2006. “How Destructive Is Creative Destruction? The Costs of Worker Displacement." IZA Discussion paper no. 2316 (September).

Imbens, Guido W. and Lisa M. Lynch. 2006. “Re-Employment Probabilities over the Business Cycle." IZA Discussion Paper no. 2167 (June).

Jacobson, Louis S., Robert L. LaLonde, and Daniel G. Sullivan. 2005. "Estimating the Returns to Community College Schooling for Displaced Workers." Journal of Econometrics, 125, pp. 271-304.

Jacobson, Louis S., Robert L. LaLonde, and Daniel G. Sullivan. 1993a. “Earnings Losses of Displaced Workers." American Economic Review, 83, no. 4 (September), pp. 685-709.

Jacobson, Louis S., Robert L. LaLonde, and Daniel G. Sullivan. 1993b. The Costs of Worker Dislocation. Kalamazoo, MI: W.E. Upjohn Institute for Employment Research.

Katz, Lawrence F. and Bruce D. Meyer. 1990. "Unemployment Insurance, Recall Expectations, and Unemployment Outcomes." The Quarterly Journal of Economics, 105, no. 4 (November), pp. 973-1002.

Kletzer, Lori G. 1998. “Job Displacement." Journal of Economic Perspectives, vol. 12, no. 1 (January), pp. 115-136.

Kodrzycki, Yolanda K. 1998. "The Effects of Employer-Provided Severance Benefits on Reemployment Outcomes." New England Economic Review, November/December, pp. 41-68.

Kodrzycki, Yolanda K. 1997. “Training Programs for Displaced Workers: What Do They Accomplish?" New England Economic Review, May/June, pp. 39-57. 
Kodrzycki, Yolanda K. 1996. "Laid-Off Workers in a Time of Structural Change." New England Economic Review, July/August, pp. 3-26.

Kodrzycki, Yolanda K. 1995. “The Costs of Defense-Related Layoffs in New England.” New England Economic Review, March/April, pp. 3-23.

Krebs, Tom. 2007. "Job Displacement Risk and the Cost of Business Cycles." American Economic Review, 97, no. 3 (June), pp. 664-686.

Kuhn, Peter and Arthur Sweetman. 1999. "Vulnerable Seniors, Firm-Specific Capital, Deferred Compensation, and Job-Match Quality." Journal of Labor Economics, part 1, vol. 17, no. 4 (October), pp. 671-693.

Lengermann, Paul A. and Lars Vihuber. 2002. "Abandoning the Sinking Ship: The Composition of Worker Flows Prior to Displacement." U.S. Census Bureau, Longitudinal Employer - Household Dynamics Technical paper no. TP-2002-11.

Office of Inspector General, U.S. Department of Labor. 2000. “The Dislocated Worker Program in a Growing Economy - Audit Period: July 1, 1997 - June 30, 1998." Report no. 0400-002-03-340 (issued June 29).

Ong, Paul M. and Don Mar. 1992. "Post-Layoff Earnings among Semiconductor Workers." Industrial and Labor Relations Review, 45, no. 2 (January), pp. 366-379.

Oreopoulos, Philip, Marianne Page, and Ann Huff Stevens. 2005. "The Intergenerational Effects of Worker Displacement." National Bureau of Economic Research Working Paper no. 11587 (August).

Roodman, David. 2006. "How to Do xtabond2: An Introduction to 'Difference' and 'System' GMM in Stata." Center for Global Development Working Paper no. 103 (revised January 2007).

Social Policy Research Associates. 1996. PY 94 SPIR Data Book: Massachusetts, prepared for Office of Policy and Research, Employment and Training Administration, U.S. Department of Labor under DOL Contract no. K-3944-2-00-80-30 (June 28).

Stevens, Ann Huff. 1997. "Persistent Effects of Job Displacement: The Importance of Multiple Job Losses." Journal of Labor Economics, 15, no.1, pp. 165-188.

Sullivan, Daniel G. and Till von Wachter. 2007. "Mortality, Mass-Layoffs, and Career Outcomes: An Analysis using Administrative Data." Working Paper. 
U.S. Department of Labor. 1996. Training and Employment Report of the Secretary of Labor (Covering the Period July 1992 - September 1993), Washington, DC: U.S. Government Printing Office.

U.S. Department of Labor. 1995. Training and Employment Report of the Secretary of Labor (Covering the Period July 1991 - September 1992), Washington, DC: U.S. Government Printing Office.

U.S. Department of Labor Employment and Training Administration. 1992. Employer Layoff and Recall Practices, Unemployment Insurance Occasional Paper 92-3 (January), Washington, DC: U.S. Government Printing Office.

Valletta, Robert G. 2005. “Rising Unemployment Duration in the United States: Causes and Consequences." Federal Reserve Bank of San Francisco Working Paper (May).

Valletta, Robert G. 1999. “Declining Job Security.” Journal of Labor Economics 17 (4, part 2), pp. S170-S197.

Wandner, Stephan A. and Andrew Stettner. 2000. "Why are many jobless workers not applying for benefits?" Monthly Labor Review, June, pp. 21-32. 
Figure 1

Share of Workers Re-Employed: Recalled versus Non-Recalled

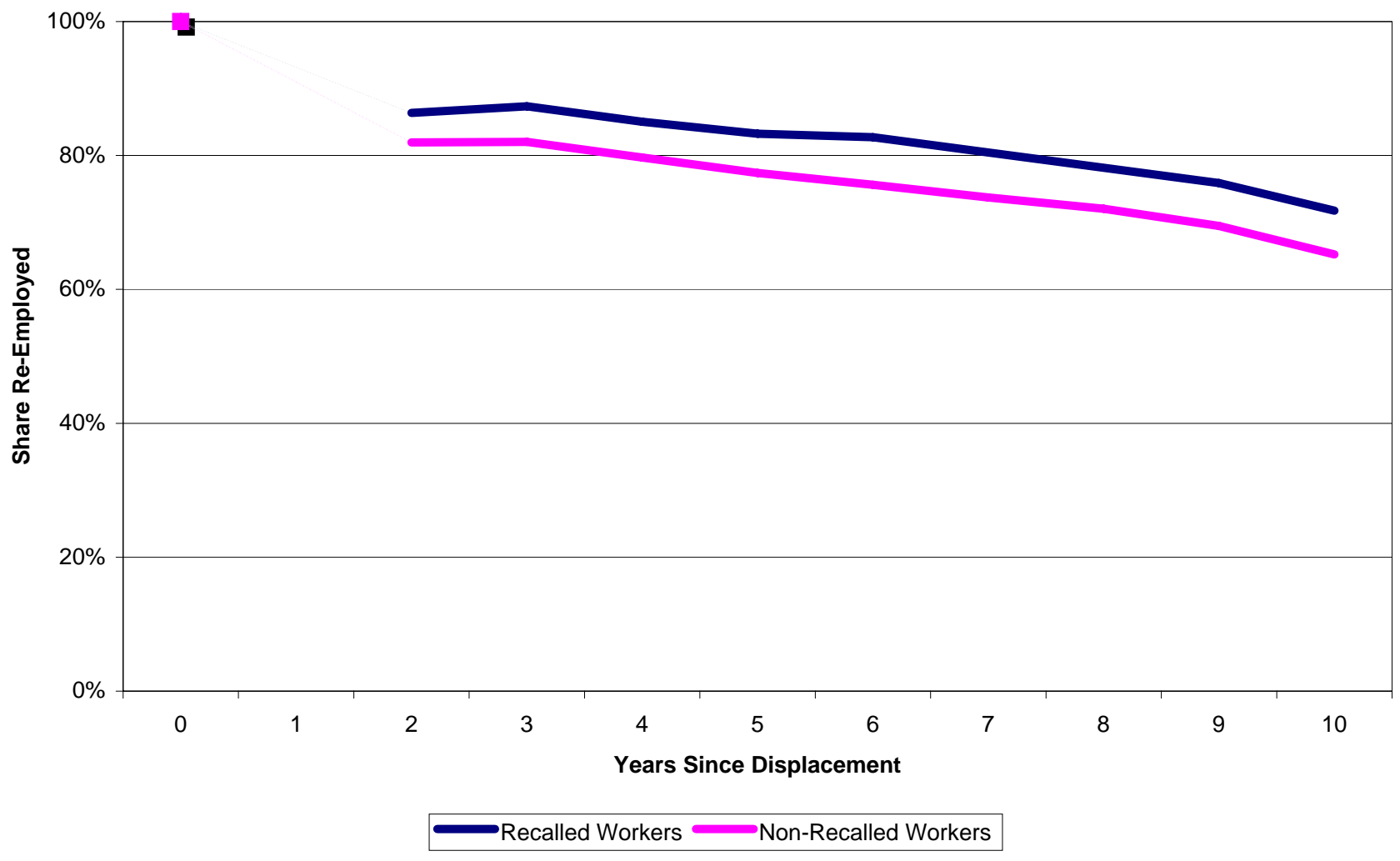

Source: Author's calculations explained in text.

Note: Data on recalled and non-recalled workers are not available until the second year after displacement. 
Figure 2

Earnings Gap: Recalled v. Non-Recalled Workers

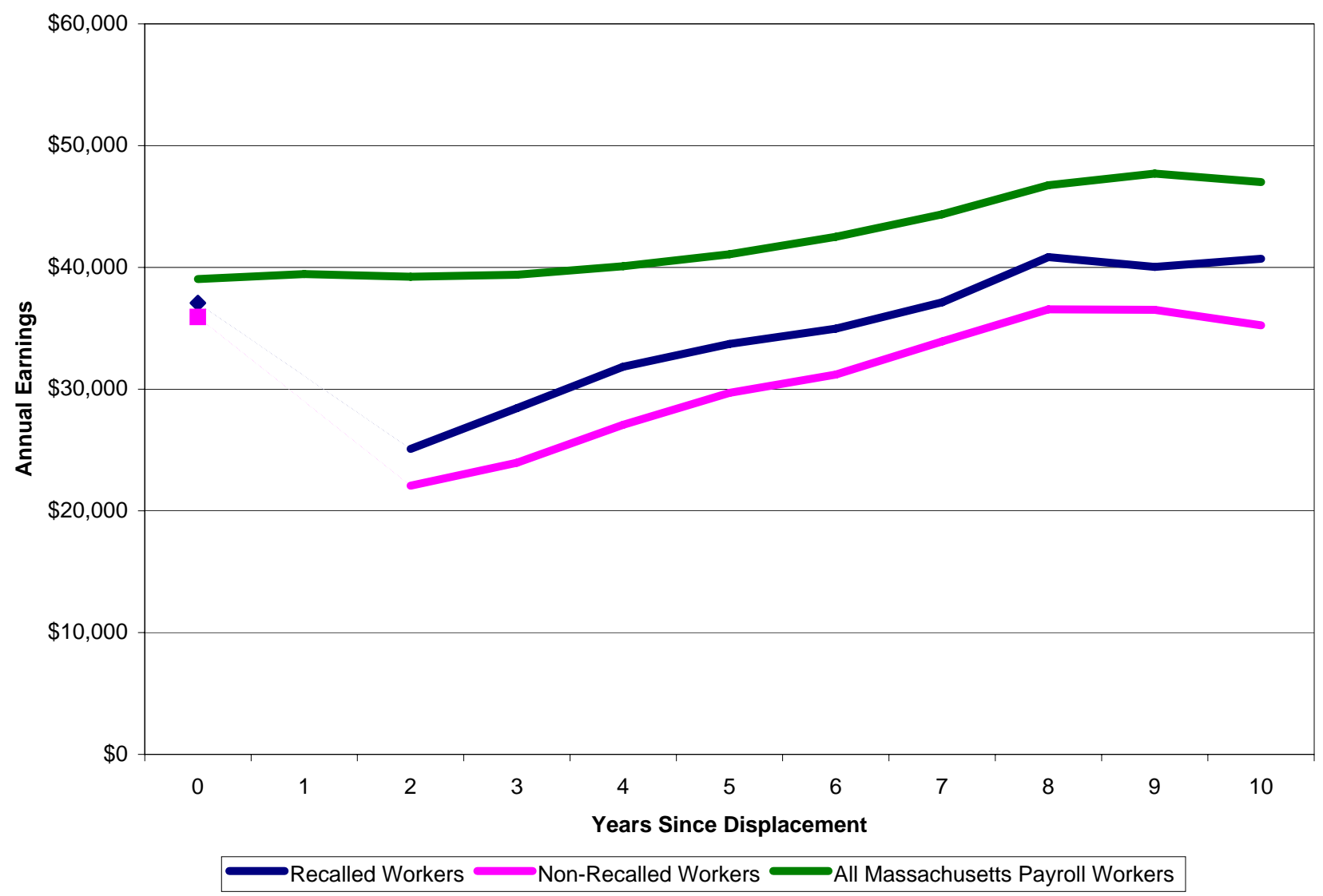

Source: Author's calculations explained in text, and Bureau of Labor Statistics

Note: Data on recalled and non-recalled workers are not available until the second year after displacement. 
Figure 3

Earnings Gap: Recalled v. Non-Recalled Former Manufacturing Workers

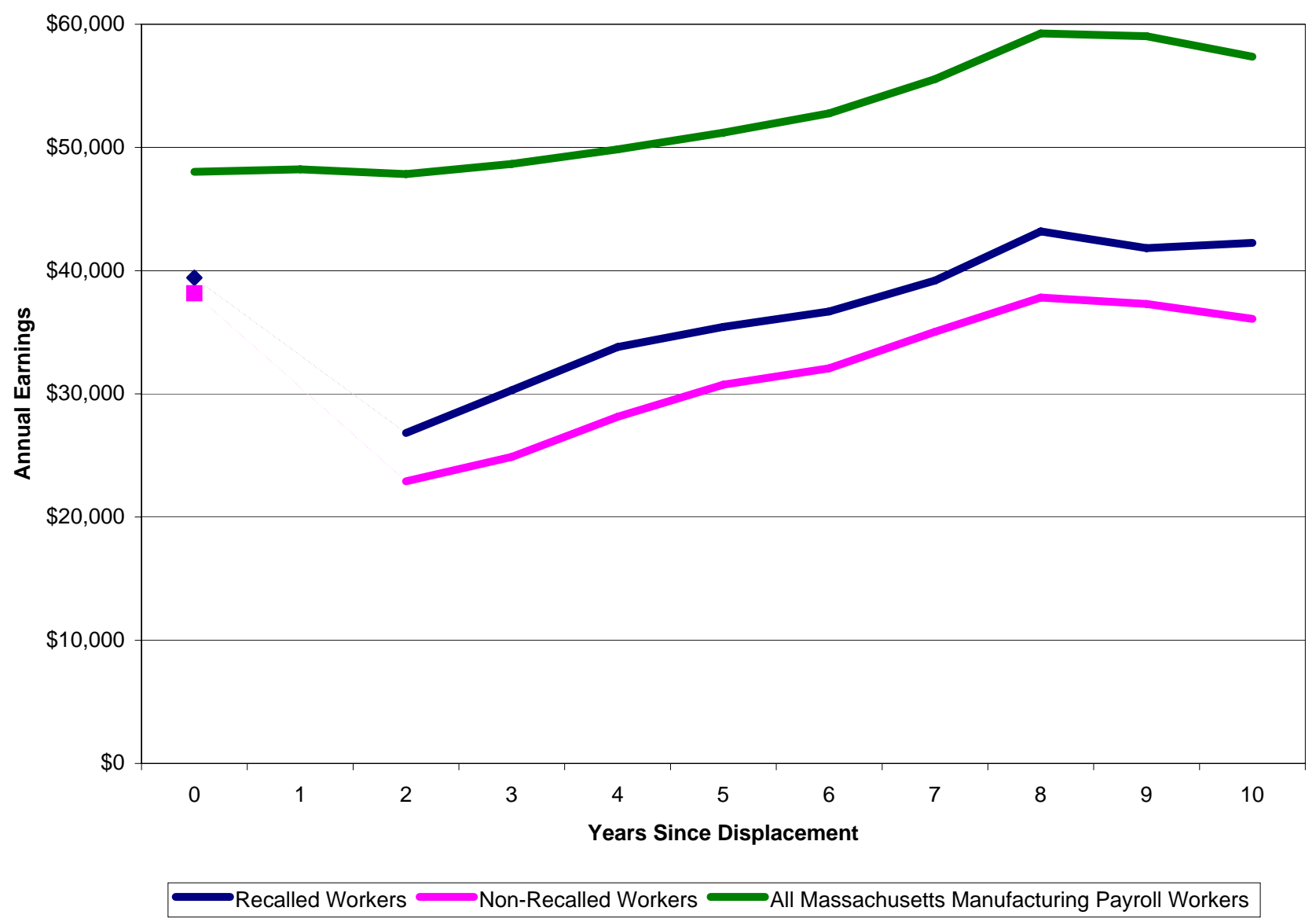

Source: Author's calculations explained in text, and Bureau of Labor Statistics

Note: Data on recalled and non-recalled workers are not available until the second year after displacement. 
Table 1

Comparison of Massachusetts Displaced Workers with National JTPA/ EDWAA Population and CPS Displaced Workers Survey (Percentages unless otherwise noted)

\begin{tabular}{|c|c|c|c|c|c|c|c|}
\hline & \multicolumn{3}{|c|}{$\begin{array}{c}\text { Massachusetts Displaced } \\
\text { Workers }\end{array}$} & \multicolumn{2}{|c|}{$\begin{array}{l}\text { JTPA/ EDWAA Samples } \\
\text { (PY } 1993 \text { and PY 1994) }\end{array}$} & \multicolumn{2}{|c|}{$\begin{array}{c}\text { CPS Displaced Worker } \\
\text { Surveys }\end{array}$} \\
\hline & (1) & $(2)$ & (3) & $(4)$ & (5) & (6) & $(7)$ \\
\hline & ISP Data & $\begin{array}{l}\text { Full Matched } \\
\text { Sample }\end{array}$ & $\begin{array}{c}\text { Regression } \\
\text { Sample }\end{array}$ & MA & US & 1994 & 1996 \\
\hline Male & $52.9 \%$ & $52.2 \%$ & $53.8 \%$ & $53.7 \%$ & $54.9 \%$ & $63.3 \%$ & $61.1 \%$ \\
\hline White & $87.1 \%$ & $87.6 \%$ & $88.8 \%$ & $86.4 \%$ & $72.7 \%$ & $86.2 \%$ & $85.4 \%$ \\
\hline \multicolumn{8}{|l|}{ Age } \\
\hline under 25 & $2.7 \%$ & $1.3 \%$ & $1.3 \%$ & $3.1 \%$ & $7.1 \%$ & $2.3 \%$ & $3.0 \%$ \\
\hline $25-34$ & $22.1 \%$ & $15.5 \%$ & $19.6 \%$ & $22.9 \%$ & $26.5 \%$ & $24.1 \%$ & $25.5 \%$ \\
\hline $35-44$ & $33.3 \%$ & $31.8 \%$ & $36.4 \%$ & $34.3 \%$ & $33.8 \%$ & $32.5 \%$ & $32.4 \%$ \\
\hline $45-54$ & $27.9 \%$ & $30.0 \%$ & $32.2 \%$ & $27.8 \%$ & $23.8 \%$ & $22.9 \%$ & $25.7 \%$ \\
\hline $55-64$ & $13.2 \%$ & $16.0 \%$ & $10.1 \%$ & $11.5 \%$ & $8.3 \%$ & $15.6 \%$ & $11.3 \%$ \\
\hline 65 and over & $0.9 \%$ & $1.6 \%$ & $0.5 \%$ & $0.5 \%$ & $0.5 \%$ & $2.9 \%$ & $2.7 \%$ \\
\hline \multicolumn{8}{|l|}{ Educational attainment } \\
\hline Less than high school & $12.4 \%$ & $12.2 \%$ & $11.4 \%$ & $9.3 \%$ & $6.5 \%$ & $13.1 \%$ & $17.3 \%$ \\
\hline High school graduate & $49.2 \%$ & $49.7 \%$ & $52.2 \%$ & $43.7 \%$ & $47.7 \%$ & $35.5 \%$ & $33.5 \%$ \\
\hline Some college & $20.0 \%$ & $19.4 \%$ & $20.0 \%$ & $22.8 \%$ & $23.2 \%$ & $31.9 \%$ & $26.4 \%$ \\
\hline College graduate & $18.1 \%$ & $18.4 \%$ & $16.3 \%$ & $22.1 \%$ & $19.5 \%$ & $19.5 \%$ & $22.9 \%$ \\
\hline Average reading score & 8.41 & $8.93^{\mathrm{a}}$ & $8.69^{\mathrm{a}}$ & $9.75^{\mathrm{b}}$ & $10.37^{b}$ & n.a. & n.a. \\
\hline Manufacturing & $62.0 \%$ & $61.7 \%$ & $64.7 \%$ & n.a. & n.a. & $36.1 \%$ & $33.6 \%$ \\
\hline \multicolumn{8}{|l|}{ Hourly Wage } \\
\hline At previous job & $\$ 13.34$ & $\$ 13.34$ & $\$ 13.48$ & $\$ 14.29$ & $\$ 11.73$ & n.a. & n.a. \\
\hline At new job & $\$ 11.54$ & $\$ 11.54$ & $\$ 11.56$ & $\$ 12.44$ & $\$ 9.68$ & n.a. & n.a. \\
\hline Mean decrease & $-10.2 \%$ & $-10.9 \%$ & $-12.4 \%$ & $-10.2 \%$ & $-9.1 \%$ & n.a. & n.a. \\
\hline Median decrease & $-10.8 \%$ & $-11.1 \%$ & $-12.8 \%$ & $-12.2 \%$ & $-14.1 \%$ & n.a. & n.a. \\
\hline Median Earnings Loss & n.a. & $28.4 \%$ & $24.4 \%$ & n.a. & n.a. & $8.2 \%$ & $13.9 \%$ \\
\hline Earnings Loss $>=20$ Percent & n.a. & $58.1 \%$ & $54.5 \%$ & n.a. & n.a. & $31.2 \%$ & $22.0 \%$ \\
\hline \multicolumn{8}{|c|}{ Earnings Loss, Manufacturing $>=20$} \\
\hline Percent & n.a. & $59.9 \%$ & $55.7 \%$ & n.a. & n.a. & $32.6 \%$ & $38.2 \%$ \\
\hline Sample Size & 19,009 & 9,146 & 3,753 & 21,675 & 406,259 & 2,519 & 2,213 \\
\hline
\end{tabular}

Note: The earnings losses in the displaced worker samples are based on comparing earnings in EY 1995 with annualized earnings in the available base period (EY1992, EY1993, or EY1995). For full matched sample earnings losses, only workers with positive postdisplacement earnings are included, as in the DWS calculation. This yields a sample size of 7,462 instead of 9,146 for the earnings comparison. The earnings losses in the DWS are based on comparing weekly earnings at the time of the survey with weekly earnings before displacement, which could have occurred during the previous 2 or 3 years. For example, in the column headed "1996," these individuals lost jobs in 1993, 1994, or 1995 and are being surveyed on their employment status in 1996 . Earnings losses are not adjusted for inflation. 


\section{Table 2}

Regression sample characteristics

\begin{tabular}{|c|c|c|c|}
\hline & Permanent Layoff & Recall & Total Sample \\
\hline Number of observations & 3,581 & 172 & 3,753 \\
\hline Percent male & $53.0 \%$ & $74.0 \%$ & $53.8 \%$ \\
\hline Percent white & $88.8 \%$ & $90.1 \%$ & $88.8 \%$ \\
\hline Percent manufacturing & $64.3 \%$ & $71.5 \%$ & $64.7 \%$ \\
\hline Average age in 1994 (years) & 43.7 & 42.6 & 43.6 \\
\hline \multicolumn{4}{|l|}{ Age distribution in 1994} \\
\hline Under 40 & $36.4 \%$ & $44.8 \%$ & $36.8 \%$ \\
\hline $40-45$ & $19.2 \%$ & $20.4 \%$ & $19.2 \%$ \\
\hline $45-50$ & $18.4 \%$ & $16.9 \%$ & $18.4 \%$ \\
\hline $50-55$ & $12.9 \%$ & $12.8 \%$ & $12.9 \%$ \\
\hline $55-60$ & $7.1 \%$ & $4.1 \%$ & $6.9 \%$ \\
\hline $60-65$ & $2.1 \%$ & $1.2 \%$ & $2.1 \%$ \\
\hline over 65 & $3.9 \%$ & $0.0 \%$ & $3.7 \%$ \\
\hline Average years of tenure (before disp) & 8.2 & 7.2 & 8.2 \\
\hline \multicolumn{4}{|l|}{ Tenure distribution } \\
\hline 5 years and less & $48.7 \%$ & $51.2 \%$ & $48.8 \%$ \\
\hline 6 to 10 years & $21.0 \%$ & $22.7 \%$ & $21.1 \%$ \\
\hline 11 to 19 years & $22.2 \%$ & $19.8 \%$ & $22.1 \%$ \\
\hline 20 and over & $8.1 \%$ & $6.4 \%$ & $8.0 \%$ \\
\hline \multicolumn{4}{|l|}{ Educational attainment } \\
\hline Less than high school & $11.6 \%$ & $8.7 \%$ & $11.4 \%$ \\
\hline High school graduate & $52.0 \%$ & $55.8 \%$ & $52.2 \%$ \\
\hline Some college & $19.8 \%$ & $23.8 \%$ & $20.0 \%$ \\
\hline College graduate & $16.5 \%$ & $11.6 \%$ & $16.3 \%$ \\
\hline Average reading score & 8.7 & 8.7 & 8.7 \\
\hline Average pre-displacement earnings & $\$ 35,928$ & $\$ 37,068$ & $\$ 35,980$ \\
\hline $\begin{array}{l}\text { Average pre-displacement earnings, } \\
\text { manufacturing workers }\end{array}$ & $\$ 38,159$ & $\$ 39,418$ & $\$ 38,223$ \\
\hline Layoff in 1992 & $46.8 \%$ & $37.2 \%$ & $46.4 \%$ \\
\hline Layoff in 1993 & $52.7 \%$ & $61.1 \%$ & $53.1 \%$ \\
\hline Layoff in 1994 & $0.5 \%$ & $1.7 \%$ & $0.6 \%$ \\
\hline
\end{tabular}


Table 3

OLS regression of pre-displacement earnings on worker characteristics and future recall status

\begin{tabular}{|c|c|c|c|c|c|c|}
\hline & \multicolumn{3}{|c|}{ All Workers } & \multicolumn{3}{|c|}{ Former Manufacturing Workers } \\
\hline & $(1)$ & (2) & (3) & (4) & (5) & (6) \\
\hline & Basic Model & $\begin{array}{l}\text { Tenure-Recall } \\
\text { Interactions }\end{array}$ & $\begin{array}{l}\text { Employer } \\
\text { Controls }\end{array}$ & Basic Model & $\begin{array}{l}\text { Tenure-Recall } \\
\text { Interactions }\end{array}$ & $\begin{array}{l}\text { Employer } \\
\text { Controls }\end{array}$ \\
\hline Recall Status & -338 & $-3768^{\star}$ & -2991 & -44 & $-5859 * *$ & $-4874^{\star \star}$ \\
\hline Male & $5724^{\star * \star}$ & $5792^{\star \star *}$ & $5963^{\star \star \star}$ & $5639 * \star \star$ & $5768^{\star \star \star}$ & $6029 * \star \star$ \\
\hline White & -768 & -817 & 828 & -1441 & -1470 & 1095 \\
\hline $\begin{array}{l}\text { Number of dependents } \\
\text { Citizenship staus } \\
\text { Veteran status }\end{array}$ & $\begin{array}{l}1192^{\star \star \star} \\
1391 \\
1183\end{array}$ & $\begin{array}{l}1186^{\star * \star} \\
1385 \\
1180\end{array}$ & $\begin{array}{l}1167^{\star * \star} \\
1019 \\
965\end{array}$ & $\begin{array}{l}1065^{\star \star \star} \\
2805^{\star \star} \\
2239^{\star \star \star}\end{array}$ & $\begin{array}{l}1057^{\star \star \star} \\
2643^{\star \star} \\
2202^{\star \star \star}\end{array}$ & $\begin{array}{l}1074^{\star \star \star} \\
2129^{\star} \\
2025^{\star \star}\end{array}$ \\
\hline $\begin{array}{l}\text { Age } 40-45 \\
\text { Age } 45-50 \\
\text { Age } 50-55 \\
\text { Age } 55-60 \\
\text { Age } 60-65 \\
\text { Age over } 65\end{array}$ & $\begin{array}{l}3072^{\star \star \star} \\
4683^{\star \star \star} \\
5629^{\star \star \star} \\
4338^{\star \star \star} \\
2679 \\
4985\end{array}$ & $\begin{array}{l}3034^{\star \star \star} \\
4641^{\star \star \star} \\
5622^{\star \star \star} \\
4403^{\star \star \star} \\
2744 \\
5130\end{array}$ & $\begin{array}{l}2775^{\star \star \star} \\
4474^{\star \star \star} \\
5062^{\star \star \star} \\
4245^{\star \star \star} \\
2099 \\
5419\end{array}$ & $\begin{array}{l}3733^{\star \star \star} \\
5030^{\star \star \star} \\
4931^{\star \star \star} \\
3696^{\star \star \star} \\
4545^{\star \star} \\
\text { n.a. }\end{array}$ & $\begin{array}{l}3691^{\star \star \star} \\
4920^{\star \star \star} \\
4988^{\star \star \star} \\
3785^{\star \star \star} \\
4679^{\star \star} \\
\text { n.a. }\end{array}$ & $\begin{array}{l}3408^{\star \star \star} \\
4660^{\star \star \star} \\
4143^{\star \star \star} \\
3389^{\star \star \star} \\
3645^{\star \star} \\
\text { n.a. }\end{array}$ \\
\hline $\begin{array}{l}\text { Tenure between } 6 \text { and } 10 \text { years } \\
\text { Tenure between } 11 \text { and } 19 \text { years } \\
\text { Tenure greater than } 20 \text { years }\end{array}$ & $\begin{array}{l}4331^{\star \star \star} \\
7731^{\star \star \star} \\
10998^{\star \star \star}\end{array}$ & $\begin{array}{l}4228^{\star \star \star} \\
7483^{\star \star \star} \\
10553^{\star \star \star}\end{array}$ & $\begin{array}{l}3945^{\star \star \star} \\
6802^{\star \star \star} \\
11065^{\star \star \star}\end{array}$ & $\begin{array}{l}3749^{\star \star \star} \\
7449^{\star \star \star} \\
9708^{\star \star \star}\end{array}$ & $\begin{array}{l}3547^{\star \star \star} \\
6980^{\star \star \star} \\
9056^{\star \star \star}\end{array}$ & $\begin{array}{l}2703^{\star \star \star} \\
5750^{\star \star \star} \\
9261^{\star \star \star}\end{array}$ \\
\hline $\begin{array}{l}\text { High school dropout } \\
\text { Some college } \\
\text { College graduate }\end{array}$ & $\begin{array}{l}-2714^{\star \star \star} \\
2944^{\star \star \star} \\
11499^{\star \star \star}\end{array}$ & $\begin{array}{l}-2636^{\star \star \star} \\
2932^{\star \star \star} \\
11450^{\star \star \star}\end{array}$ & $\begin{array}{l}-1920^{\star \star} \\
2291^{\star \star \star} \\
10665^{\star \star \star}\end{array}$ & $\begin{array}{l}-2284^{\star \star \star} \\
2880^{\star \star \star} \\
13361^{\star \star \star}\end{array}$ & $\begin{array}{l}-2150^{\star \star} \\
2851^{\star \star \star} \\
13248^{\star \star \star}\end{array}$ & $\begin{array}{l}-1347 \\
2117^{\star \star \star} \\
12302^{\star \star \star}\end{array}$ \\
\hline Manufacturing worker & $3062^{\star \star \star}$ & $3047^{\star \star *}$ & $1604^{\star \star \star}$ & n.a. & n.a. & n.a. \\
\hline Reading test score & $776^{\star \star \star}$ & $767^{\star \star \star}$ & $718^{\star \star \star}$ & $864^{\star \star \star}$ & $846^{\star \star *}$ & $737^{\star \star \star}$ \\
\hline $\begin{array}{l}\text { Tenure * Recall } \\
\text { Tenure squared * Recall }\end{array}$ & & $\begin{array}{l}421 \\
3\end{array}$ & $\begin{array}{l}239 \\
11\end{array}$ & & $\begin{array}{l}707 \\
0\end{array}$ & $\begin{array}{l}480 \\
10\end{array}$ \\
\hline Constant term & $7661^{\star \star *}$ & $7855^{\star \star \star}$ & $7943^{\star \star \star}$ & $9328^{\star \star \star}$ & $9764^{\star \star \star}$ & $8315^{\star \star \star}$ \\
\hline Adjusted R-squared & 0.34 & 0.35 & 0.39 & 0.38 & 0.39 & 0.44 \\
\hline Number of observations & 3,449 & 3,449 & 3,449 & 2,165 & 2,165 & 2,165 \\
\hline $\begin{array}{l}\text { Number of observations with a control } \\
\text { for employer }\end{array}$ & n.a. & n.a. & 1,572 & n.a. & n.a. & 1,329 \\
\hline
\end{tabular}

Note: ${ }^{* \star}$ denotes significantly different from zero at the $1 \%$ level, ${ }^{* \star}$ at the $5 \%$ level, and ${ }^{*}$ at the $10 \%$ level. Regressions also control for quarter of displacement. The dependent variable is in 2004 Q1 dollars. 
Table 4

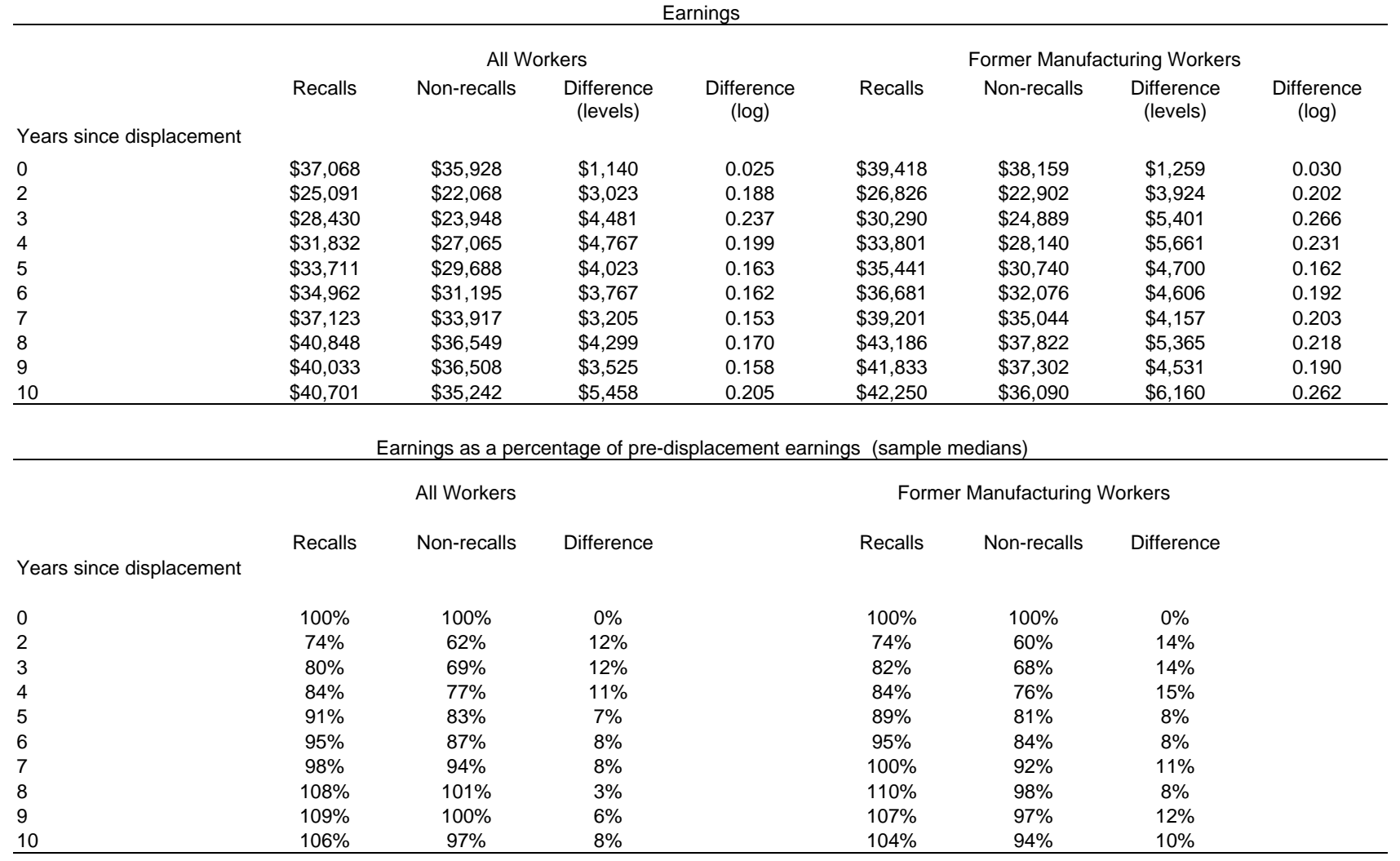


Table 5

Effects of Recall on Post-Displacement Earnings

Fixed-effects regression with clustered standard errors

All Workers

Years since layoff

(1)

(2)

(3)

3

$.211^{\star \star \star}$

(0.069)

$0.203^{\star * *}$

(0.050)

$.159 * * \star$

4

(0.046)

5

$.127^{\star *}$

(0.050)

6

$.128^{\star \star *}$

(0.069)

$.114^{\star *}$

(0.051)

$.142^{\star \star *}$

(0.047)

$.133^{\star *}$

$(0.052)$

$.174^{\star \star *}$

10

(0.067)

$208^{\star \star *}$

(0.068) (0.071)

$.198^{\star \star *} \quad .205^{\star \star *}$

(0.049) (0.051)

$.150 * \star \star \quad .148 * \star \star$

(0.045) (0.047)

$.118^{* *} \quad .112^{\text {** }}$

(0.049) (0.051)

$.111^{\star \star} \quad .105^{\star \star}$

(0.047) (0.049)

$.094^{*} \quad 0.0815$

(0.050) (0.052)

$.121^{\star * *} \quad .109 * *$

(0.046) (0.048)

.102 ** .088*

(0.051) (0.052)

.139 ** $0.13^{*}$

(0.066) (0.069)

Number of observations

3,753

3,753

R-squared

0.057

0.077

3,453

0.087

Former Manufacturing Workers

Years since layoff

\begin{tabular}{|c|c|c|c|}
\hline \multirow[t]{2}{*}{2} & $.219 * \star \star$ & $.216^{\star \star \star}$ & $.215^{\star \star}$ \\
\hline & $(0.081)$ & $(0.080)$ & $(0.084)$ \\
\hline \multirow[t]{2}{*}{3} & $.226^{\star \star *}$ & 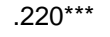 & $.226^{\star \star *}$ \\
\hline & $(0.057)$ & $(0.057)$ & $(0.059)$ \\
\hline \multirow[t]{2}{*}{4} & $.187^{\star \star *}$ & $.175^{\star \star \star}$ & $.171^{\star \star \star}$ \\
\hline & $(0.052)$ & $(0.052)$ & $(0.053)$ \\
\hline \multirow[t]{2}{*}{5} & $.127^{\star \star}$ & $.114^{*}$ & $0.102^{*}$ \\
\hline & $(0.061)$ & $(0.060)$ & $(0.062)$ \\
\hline \multirow[t]{2}{*}{6} & $.156^{\star \star \star}$ & $.132^{\star \star}$ & $.123^{\star \star}$ \\
\hline & $(0.055)$ & $(0.054)$ & $(0.056)$ \\
\hline \multirow[t]{2}{*}{7} & $.161^{\star \star *}$ & $.137^{\star \star}$ & $.121^{\star \star}$ \\
\hline & $(0.057)$ & $(0.057)$ & $(0.059)$ \\
\hline \multirow[t]{2}{*}{8} & $.192^{\star \star \star}$ & $.167^{\star \star \star}$ & $.154^{\star \star *}$ \\
\hline & $(0.055)$ & $(0.055)$ & $(0.057)$ \\
\hline \multirow[t]{2}{*}{9} & $.173^{\star * \star}$ & $.138^{\star *}$ & $.120^{\star \star}$ \\
\hline & $(0.062)$ & $(0.061)$ & $(0.062)$ \\
\hline \multirow[t]{2}{*}{10} & $.235^{\star \star \star}$ & $.198^{\star \star \star}$ & $.188^{\star \star *}$ \\
\hline & $(0.061)$ & $(0.061)$ & $(0.062)$ \\
\hline Number of observations & 2,427 & 2,427 & 2,168 \\
\hline R-squared & 0.056 & 0.103 & 0.121 \\
\hline \multicolumn{4}{|l|}{ Controls for: } \\
\hline Age & No & Yes & Yes \\
\hline Job Tenure & No & Yes & Yes \\
\hline Education & No & Yes & Yes \\
\hline Reading test score & No & No & Yes \\
\hline
\end{tabular}

Note: *** denotes significantly different from zero at the $1 \%$ level, ** at the $5 \%$ level, and * at the $10 \%$ level. Each regression also controls for years since layoff, sex interacted with years since layoff, and earnings year. The dependent variable is in log dollars. 
Table 6

Earnings losses compared to Jacobson, LaLonde, and Sullivan ${ }^{\mathrm{a}}$

\begin{tabular}{lccc}
\hline & & Years Since Displacement \\
\cline { 2 - 4 } & 1 to 2 & 3 to 6 & 7 to $^{2}$ \\
$\begin{array}{l}\text { Earnings losses of separators, relative to } \\
\text { stayers, JLS data }\end{array}$ & $-0.45^{\mathrm{b}}$ & -0.33 & $-0.24^{\mathrm{c}}$ \\
$\begin{array}{l}\text { Losses of non-recalled workers, relative to } \\
\text { recalls }\end{array}$ & -0.21 & -0.14 & -0.11 \\
Difference & 0.24 & 0.19 & 0.13
\end{tabular}

Note: ${ }^{a}$ Results in Table 5, column 3, compared with Sullivan and von Wachter (2007), Table 8, panel B. ${ }^{\mathrm{b}}$ Period covers years since displacement 0 to 2 . ${ }^{\mathrm{C}}$ Period covers years since displacement 7 to 11 . 
Table 7

Effects of Recall on Post-Displacement Earnings

Random-effects regressions

All Workers

Years since layoff

With Clustered Standard Errors

$\frac{\text { With Clustered Standard Errors }}{(1)}$

With AR(1) Disturbances

\begin{tabular}{|c|c|c|c|c|c|c|}
\hline \multirow[t]{2}{*}{2} & $.177^{\star \star \star}$ & $.177^{\star \star \star}$ & $.181^{\star \star \star}$ & $.194^{\star \star \star}$ & $.194^{\star \star \star}$ & $.198^{\star * *}$ \\
\hline & $(0.061)$ & $(0.061)$ & $(0.064)$ & $(0.056)$ & $(0.055)$ & $(0.057)$ \\
\hline \multirow[t]{2}{*}{3} & $.173^{\star \star \star}$ & $.168^{\star \star *}$ & $.176^{\star \star \star}$ & $.174^{\star \star \star}$ & $.170^{\star \star \star}$ & $.178^{\star \star \star}$ \\
\hline & $(0.040)$ & $(0.040)$ & $(0.042)$ & $(0.049)$ & $(0.005)$ & $(0.050)$ \\
\hline \multirow[t]{2}{*}{4} & $.130^{\star \star \star}$ & $.123^{\star \star \star}$ & $.122^{\star \star \star}$ & $.128^{\star \star}$ & $.123^{\star \star}$ & $.121^{\star \star}$ \\
\hline & $(0.038)$ & $(0.038)$ & $(0.040)$ & $(0.052)$ & $(0.051)$ & $(0.053)$ \\
\hline \multirow[t]{2}{*}{5} & $.098^{\star \star}$ & $.093^{\star \star}$ & $.088^{\star \star}$ & $.095^{\star}$ & $.093^{\star}$ & 0.087 \\
\hline & $(0.041)$ & $(0.040)$ & $(0.042)$ & $(0.053)$ & $(0.052)$ & $(0.053)$ \\
\hline \multirow[t]{2}{*}{6} & $.098^{\star \star}$ & $.089 * \star$ & $.083^{\star \star}$ & $.096^{\star}$ & $.090^{*}$ & 0.083 \\
\hline & (0.039) & (0.039) & $(0.040)$ & $(0.053)$ & (0.052) & $(0.054)$ \\
\hline \multirow[t]{2}{*}{7} & $.084^{\star \star}$ & $.075^{\star}$ & 0.063 & 0.082 & 0.075 & 0.062 \\
\hline & $(0.042)$ & $(0.041)$ & $(0.043)$ & $(0.053)$ & $(0.052)$ & $(0.054)$ \\
\hline \multirow[t]{2}{*}{8} & $.112^{\star \star \star}$ & $.100^{\star \star}$ & $.089 * \star$ & .109 ** & 0.1 & 0.088 \\
\hline & $(0.039)$ & $(0.039)$ & $(0.041)$ & $(0.053)$ & $(0.052)$ & $(0.054)$ \\
\hline \multirow[t]{2}{*}{9} & $.104^{\star \star}$ & $.082^{\star}$ & 0.068 & $.101^{\star}$ & 0.08 & 0.069 \\
\hline & $(0.044)$ & $(0.043)$ & $(0.043)$ & $(0.053)$ & $(0.052)$ & $(0.054)$ \\
\hline \multirow[t]{2}{*}{10} & $.144^{\star \star}$ & $.118^{\star}$ & $.111^{\star}$ & $.143^{\star \star \star}$ & $.122^{\star \star}$ & $.114^{\star \star}$ \\
\hline & $(0.065)$ & $(0.065)$ & $(0.067)$ & $(0.054)$ & $(0.053)$ & $(0.054)$ \\
\hline Number of observations & 3,753 & 3,753 & 3,453 & 3,753 & 3,753 & 3,453 \\
\hline R-squared & 0.092 & 0.155 & 0.156 & 0.092 & 0.158 & 0.158 \\
\hline autocorrelation coefficient & -- & -- & -- & 0.361 & 0.349 & 0.353 \\
\hline
\end{tabular}

Former Manufacturing Workers

\begin{tabular}{|c|c|c|c|c|c|c|}
\hline & \multicolumn{3}{|c|}{ With Clustered Standard Errors } & \multicolumn{3}{|c|}{ With AR(1) Disturbances } \\
\hline & (1) & $(2)$ & (3) & (1) & $(2)$ & (3) \\
\hline & \multicolumn{6}{|c|}{ Years since layoff } \\
\hline \multirow[t]{2}{*}{2} & $.187^{\star \star}$ & $.178^{\star \star}$ & $.174^{\star \star}$ & $.210 * \star \star$ & $.205^{\star \star \star}$ & $.202^{\star \star \star}$ \\
\hline & $(0.075)$ & $(0.075)$ & $(0.079)$ & $(0.064)$ & $(0.063)$ & $(0.065)$ \\
\hline \multirow[t]{2}{*}{3} & $.197^{\star \star \star}$ & $.182^{\star \star \star}$ & $.184^{\star \star \star}$ & $.196^{\star \star \star}$ & $.184^{\star \star \star}$ & $.189 * * *$ \\
\hline & $(0.045)$ & $(0.045)$ & $(0.047)$ & $(0.058)$ & $(0.057)$ & $(0.059)$ \\
\hline \multirow[t]{2}{*}{4} & $.158^{\star \star *}$ & $.142^{\star \star \star}$ & $.133^{\star \star \star}$ & $.156^{\star \star}$ & $.142^{\star \star}$ & $.134^{\star *}$ \\
\hline & $(0.042)$ & $(0.041)$ & $(0.043)$ & $(0.062)$ & $(0.060)$ & $(0.062)$ \\
\hline \multirow[t]{2}{*}{5} & $.098^{\star}$ & $.083^{\star}$ & 0.067 & 0.096 & 0.083 & 0.066 \\
\hline & $(0.051)$ & $(0.049)$ & $(0.052)$ & $(0.063)$ & $(0.061)$ & $(0.063)$ \\
\hline \multirow[t]{2}{*}{6} & $.127^{\star \star \star}$ & $.104^{\star \star}$ & $.091^{\star *}$ & $.125^{\star \star}$ & $.106^{*}$ & 0.092 \\
\hline & $(0.044)$ & $(0.042)$ & $(0.044)$ & $(0.063)$ & (0.061) & $(0.063)$ \\
\hline \multirow[t]{2}{*}{7} & $.132^{\star \star \star}$ & $.111^{\star \star \star}$ & $.091^{\star \star}$ & $.130^{\star \star}$ & $.112^{\star}$ & 0.091 \\
\hline & $(0.044)$ & $(0.043)$ & $(0.449)$ & $(0.063)$ & (0.061) & $(0.063)$ \\
\hline \multirow[t]{2}{*}{8} & $.163^{\star \star *}$ & $.142^{\star \star \star}$ & $.123^{\star \star \star}$ & $.161^{\star \star}$ & $.141^{\star \star}$ & $.122^{\star}$ \\
\hline & $(0.044)$ & $(0.044)$ & $(0.045)$ & $(0.063)$ & $(0.061)$ & $(0.063)$ \\
\hline \multirow[t]{2}{*}{9} & $.144^{\star \star \star}$ & $.114^{\star \star}$ & $.091^{\star}$ & $.142^{\star \star}$ & $.115^{\star}$ & 0.09 \\
\hline & $(0.052)$ & $(0.051)$ & $(0.051)$ & $(0.063)$ & $(0.061)$ & $(0.063)$ \\
\hline \multirow[t]{2}{*}{10} & $.207^{\star \star \star}$ & $.174^{\star \star \star}$ & $.160^{\star \star}$ & $.206^{\star \star \star}$ & $.178^{\star \star \star}$ & $.163^{\star \star}$ \\
\hline & $(0.061)$ & $(0.062)$ & $(0.063)$ & $(0.063)$ & $(0.062)$ & $(0.064)$ \\
\hline Number of observations & 2,427 & 2,427 & 2,168 & 2,427 & 2,427 & 2,168 \\
\hline R-squared & 0.097 & 0.182 & 0.185 & 0.098 & 0.185 & 0.186 \\
\hline autocorrelation coefficient & -- & -- & -- & 0.363 & 0.347 & 0.352 \\
\hline \multicolumn{7}{|l|}{ Controls for: } \\
\hline Age & No & Yes & Yes & No & Yes & Yes \\
\hline Job Tenure & No & Yes & Yes & No & Yes & Yes \\
\hline Education & No & Yes & Yes & No & Yes & Yes \\
\hline Reading test score & No & No & Yes & No & No & Yes \\
\hline
\end{tabular}

Note: ${ }^{* \star *}$ denotes significantly different from zero at the $1 \%$ level, ** at the $5 \%$ level, and * at the $10 \%$ level. Each regression also controls for years since layoff, sex interacted with years since layoff, and earnings year. The dependent variable is in log dollars. 
Table 8

Effects of Recall on Post-Displacement Earnings

Dynamic panel-data estimation, one-step system GMM Orthogonal deviations transform

\section{All Workers}

Years since layoff

\section{2}

3

4

5

6

7

8

9

10

Number of observations

Test for AR(2) in first differences

$.193^{* * *}$

$(0.065)$

$.098^{\star *}$

$(0.039)$

0.019

$(0.034)$

0.013

$(0.034)$

0.032

$(0.035)$

0.018

(0.031)

$.054^{*}$

(0.032)

0.029

(0.036)

0.078

$(0.057)$

3,753

1.70

$.192^{\star * *}$

(0.064)

$.098^{\star \star}$

(0.038)

0.019

(0.034)

0.013

(0.034)

0.03

$(0.035)$

0.016

(0.031)

0.05

(0.032)

0.02

(0.036)

0.067

(0.058)

$.199^{\star \star \star}$

(0.068)

$.106^{\star \star *}$

(0.040)

0.103

(0.036)

0.007

(0.035)

0.026

$(0.037)$

0.006

$(0.032)$

0.043

(0.033)

0.012

$(0.037)$

0.065 (0.060)

Former Manufacturing Workers

Years since layoff

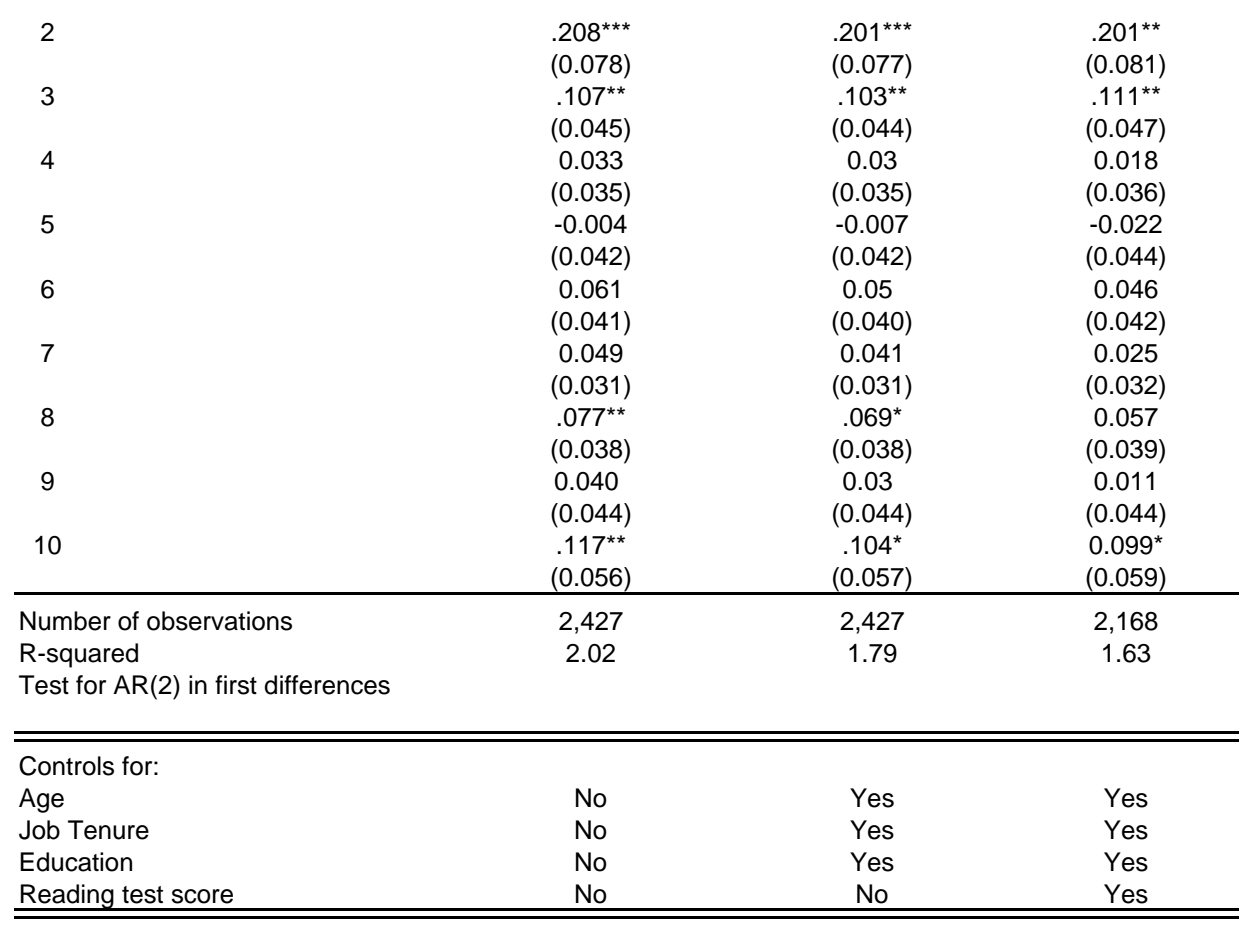

Note: ${ }^{* \star}$ denotes significantly different from zero at the $1 \%$ level, ** at the $5 \%$ level, and * at the $10 \%$ level. Each regression also controls for years since layoff, sex interacted with years since layoff, and earnings year. The dependent variable is in log dollars. 


\section{Table 9}

Random-effects regression

Subgroup:

Effect of subgroup

Effect of Recall on Subgroup

Between 1 and 3 years

Between 4 and 9 years

10 or more years

Years since displacement
Older Workers

(1)

$-0.151^{* \star *}$

(0.019)

0.119

(0.093)

0.086

$(0.070)$

0.099

(0.098)
Less Educated Workers

(2)

$-.266^{\star \star \star}$

(0.017)

$.267^{\star \star *}$

(0.055)

$.169 * \star *$

(0.041)

$0.228^{\star \star \star}$

(0.059)
High Tenure

Workers

(3)

$.042^{\star \star}$

(0.018)

0.038

(0.086)

0.104

(0.065)

$.175^{*}$

(0.092)

\section{Between 1 and 3 years \\ Between 4 and 9 years \\ 10 or more years}

Male

Number of observations

R-squared

$$
\begin{aligned}
& -.512^{\star \star *} \\
& (0.012) \\
& -.148^{\star \star *} \\
& (0.010) \\
& -.184^{\star \star *} \\
& (0.012)
\end{aligned}
$$

$.345^{\star \star \star}$

(0.017)

$$
\begin{aligned}
& 3,753 \\
& 0.090
\end{aligned}
$$

$\begin{array}{cc}-.519^{\star \star \star} & -.511^{\star \star \star} \\ (0.012) & (0.012) \\ -.152^{\star \star *} & -.148^{\star \star *} \\ (0.010) & (0.010) \\ -.189^{\star \star \star} & -.185^{\star \star \star} \\ (0.012) & (0.012)\end{array}$

$.310^{\star * *}$

$.347^{\star \star \star}$

(0.016)

(0.017)

Note: ${ }^{* \star}$ denotes significantly different from zero at the $1 \%$ level, ${ }^{* *}$ at the $5 \%$ level, and ${ }^{*}$ at the $10 \%$ level. Older workers are those over 45 years of age at the time of displacement. Less educated workers are those with a high school education or less. High-tenure workers are those with more than 10 years of tenure. The dependent variable is in log dollars. 
Table 10

Distribution of recalled and all workers across firms in regression sample

\begin{tabular}{ccccc} 
Number of recalled workers & \multicolumn{2}{c}{$\begin{array}{l}\text { Number of firms recalling this } \\
\text { many workers }\end{array}$} & $\begin{array}{l}\text { Cumulative number of recalled } \\
\text { workers }\end{array}$ & $\begin{array}{l}\text { Cumulative total number of } \\
\text { workers }\end{array}$ \\
\hline 0 & 954 & 0 & 2,352 \\
1 & 59 & 59 & 2,746 \\
2 & 9 & 77 & 2,928 \\
3 & 4 & 99 & 2,985 \\
4 & 2 & 106 & 3,995 \\
9 & 1 & 116 & 3,289 \\
10 & 1 & 130 & 3,341 \\
14 & 1 & 145 & 3,492 \\
& 15 & 1 & 172 & 3,753 \\
\hline
\end{tabular}




\section{Table 11}

Earnings loss for strictly confirmed recalls

$\begin{array}{lrr} & \text { Non-recalls } & \text { Recalls } \\ \text { Workers from firms with strictly confirmed recalls } & & \\ \text { Predisplacement Earnings } & \$ 40,614 & \$ 49,549 \\ \text { Earnings in 1995 } & \$ 25,269 & \$ 37,160 \\ \text { Difference } & -\$ 15,344 & -\$ 12,390 \\ \text { Percent Change } & -37.78 \% & -25.00 \% \\ \text { Number of workers } & 364 & 41 \\ & & \\ \text { All workers in regression sample } & & \$ 37,068 \\ & & \$ 25,910 \\ \text { Predisplacement Earnings } & \$ 35,928 & -\$ 11,158 \\ \text { Earnings in 1995 } & \$ 21,871 & -30.10 \% \\ \text { Difference } & -\$ 14,057 & 172 \\ \text { Percent Change } & -39.13 \% & 3,753 \\ \text { Number of workers } & & \end{array}$

Note: Strictly confirmed recalls are defined in the text. 
Appendix Table 1

Coefficients of controls in wage regressions

\begin{tabular}{|c|c|c|c|c|}
\hline \multirow[b]{2}{*}{ Estimation method: } & \multicolumn{4}{|c|}{ All Workers } \\
\hline & Fixed Effects & Random Effects & $\begin{array}{c}\text { Random Effects } \\
\text { with AR (1) }\end{array}$ & System GMM \\
\hline Lagged earnings & -- & -- & -- & $.5659 * \star \star$ \\
\hline 2 Years Since Displacement & 0.217 & 0.157 & 0.045 & 0.099 \\
\hline 3 Years Since Displacement & 0.371 * & 0.264 & 0.156 & 0.237 *** \\
\hline 4 Years Since Displacement & 0.431 * & 0.280 & 0.157 & 0.185 ** \\
\hline 5 Years Since Displacement & 0.429 ** & 0.297 & 0.165 & 0.183 ** \\
\hline 6 Years Since Displacement & 0.538 ** & 0.300 & 0.161 & 0.162 ** \\
\hline 7 Years Since Displacement & $0.566 * *$ & 0.288 & 0.143 & $0.137 * *$ \\
\hline 8 Years Since Displacement & 0.580 ** & 0.265 & 0.113 & 0.108 ** \\
\hline 9 Years Since Displacement & 0.580 ** & 0.227 & 0.068 & 0.071 \\
\hline 10 Years Since Displacement & $0.580 * *$ & 0.190 & 0.026 & 0.047 \\
\hline 11 Years Since Displacement & 0.566 ** & 0.142 & -0.034 & \\
\hline Male * 1 year & 0.191 & 0.329 & 0.226 & 0.155 \\
\hline Male * 2 years & 0.048 & $0.197^{\star * \star}$ & 0.152 *** & 0.164 \\
\hline Male * 3 years & 0.031 & $0.180 * * *$ & 0.152 *** & 0.119 \\
\hline Male * 4 years & 0.067 ** & 0.214 *** & 0.214 *** & $0.157 * \star *$ \\
\hline Male * 5 years & 0.068 ** & $0.215^{* * *}$ & 0.225 *** & $0.137 * * *$ \\
\hline Male *6 years & 0.058 ** & 0.204 *** & 0.217 *** & $0.128 * \star *$ \\
\hline Male * 7 years & 0.041 & $0.187 * * \star$ & $0.202 * * *$ & $0.116 * * *$ \\
\hline Male * 8 years & 0.043 & $0.187^{\star * \star *}$ & 0.203 *** & 0.122 *** \\
\hline Male * 9 years & $0.086 * * *$ & $0.229 * * *$ & 0.246 *** & $0.166 * \star *$ \\
\hline Male * 10 years & 0.090 *** & 0.234 *** & 0.251 *** & 0.147 *** \\
\hline Male * 11 years & 0.085 ** & 0.226 *** & 0.253 *** & $0.149 * \star *$ \\
\hline Year 1995 & $-0.886 * * *$ & $-0.890 * * *$ & $-0.762 * \star *$ & $-0.601 * * *$ \\
\hline Year 1996 & $-0.799 * * *$ & -0.758 *** & $-0.638 * * *$ & -0.117 * \\
\hline Year 1997 & $-0.737 * \star \star$ & $-0.655 * \star \star$ & $-0.534 * \star \star$ & -0.077 \\
\hline Year 1998 & $-0.703 * * *$ & $-0.580 * * *$ & $-0.455 * \star$ & -0.048 \\
\hline Year 1999 & -0.702 *** & -0.540 ** & -0.410 ** & -0.037 \\
\hline Year 2000 & -0.594 ** & -0.394 * & -0.260 & 0.099 ** \\
\hline Year 2001 & -0.561 ** & -0.324 & -0.186 & $0.098 * * *$ \\
\hline Year 2002 & -0.640 ** & -0.367 & -0.224 & 0.027 \\
\hline Year 2003 & $-0.737 * \star *$ & -0.431 * & -0.284 & \\
\hline Age $40-45$ & 0.021 & -0.086 ** & $-0.093 * *$ & $-0.052 *$ \\
\hline Age $45-50$ & -0.072 & $-0.237 * * *$ & -0.220 *** & -0.157 *** \\
\hline Age $50-55$ & -0.064 & $-0.262 * \star *$ & $-0.252 * * *$ & $-0.143 * * *$ \\
\hline Age $55-60$ & -0.074 & $-0.288 * * \star$ & -0.302 *** & $-0.184 * * *$ \\
\hline Age $60-65$ & $-0.497 * \star \star$ & $-0.688 * \star \star$ & -0.658 *** & $-0.359 * * *$ \\
\hline Age over 65 & $-0.920 * * *$ & $-1.021 * \star *$ & $-0.839 * \star *$ & $-0.356 * * *$ \\
\hline Age $40-45 *$ Tenure 6-10 & $-0.097 * * \star$ & -0.031 & -0.023 & -0.025 \\
\hline Age $40-45 *$ Tenure $11-19$ & $-0.142 * \star \star *$ & -0.006 & 0.012 & -0.018 \\
\hline Age $40-45 *$ Tenure over 20 & -0.222 & 0.067 & 0.072 & -0.102 * \\
\hline Age $45-50 *$ Tenure $6-10$ & $-0.132 * * \star$ & -0.027 & -0.001 & 0.001 \\
\hline Age $45-50$ * Tenure $11-19$ & $-0.190 * * *$ & 0.004 & 0.032 & 0.026 \\
\hline Age $45-50$ * Tenure over 20 & -0.291 ** & 0.039 & 0.085 * & -0.013 \\
\hline Age $50-55 *$ Tenure $6-10$ & -0.081 & 0.054 * & 0.054 & $0.051 * *$ \\
\hline Age $50-55 *$ Tenure $11-19$ & -0.191 *** & 0.049 & 0.072 ** & 0.049 ** \\
\hline Age $50-55$ * Tenure over 20 & -0.288 * & 0.070 * & 0.085 ** & -0.004 \\
\hline Age $55-60 *$ Tenure 6-10 & -0.067 & 0.093 ** & 0.107 ** & $0.062 * *$ \\
\hline Age $55-60$ * Tenure $11-19$ & $-0.191 * * *$ & 0.062 * & 0.088 ** & 0.066 ** \\
\hline Age $55-60$ * Tenure over 20 & $-0.447 * \star \star$ & -0.078 * & -0.058 & -0.039 \\
\hline Age $60-65 *$ Tenure $6-10$ & -0.110 & 0.059 & 0.084 & 0.005 \\
\hline Age $60-65 *$ Tenure $11-19$ & -0.164 ** & 0.094 * & 0.128 ** & 0.087 * \\
\hline Age $60-65$ * Tenure over 20 & -0.371 ** & -0.006 & -0.020 & 0.021 \\
\hline Age over $65 *$ Tenure $6-10$ & 0.045 & 0.223 ** & 0.170 * & 0.126 \\
\hline Age over $65 *$ Tenure $11-19$ & -0.083 & 0.174 ** & 0.138 & 0.035 \\
\hline Age over $65 *$ Tenure over 20 & $-0.757 * * *$ & $-0.415 * * *$ & $-0.425 * * *$ & -0.215 * \\
\hline Age 40-45* High School Dropout & 0.036 & -0.034 & -0.049 & -0.034 \\
\hline Age $40-45$ * Some College & 0.048 & $0.067 * * *$ & 0.062 ** & 0.028 \\
\hline Age $40-45 *$ College Graduate & -0.030 & $0.143 * \star *$ & $0.159 * \star \star$ & 0.091 *** \\
\hline Age 45-50 * High School Dropout & 0.006 & -0.070 * & -0.093 ** & $-0.076 * * *$ \\
\hline Age $45-50$ * Some College & 0.091 ** & $0.101 * \star \star$ & 0.092 *** & 0.046 ** \\
\hline Age $45-50$ * College Graduate & 0.081 ** & $0.289 * * *$ & 0.314 *** & 0.162 *** \\
\hline Age 50-55* High School Dropout & -0.082 & $-0.153 * \star *$ & $-0.180 * \star *$ & -0.086 ** \\
\hline Age 50-55* Some College & 0.131 *** & $0.137 * * *$ & 0.120 *** & 0.049 ** \\
\hline Age $50-55$ * College Graduate & 0.084 * & $0.301 * * *$ & $0.315 * * *$ & $0.139 * * *$ \\
\hline Age 55-60 * High School Dropout & -0.028 & -0.088 * & -0.115 ** & -0.038 \\
\hline Age 55-60* Some College & 0.077 & 0.089 ** & 0.092 ** & 0.038 \\
\hline Age $55-60 *$ College Graduate & 0.122 ** & $0.321 * \star \star$ & $0.325 * \star *$ & 0.126 *** \\
\hline Age over $65 *$ High School Dropo & $-0.125 *$ & $-0.167 * \star *$ & -0.150 ** & -0.089 \\
\hline Age over 65 * Some College & 0.042 & 0.063 & 0.062 & 0.032 \\
\hline Age over $65 *$ College Graduate & -0.066 & 0.095 ** & 0.097 * & -0.031 \\
\hline Age $40-45 *$ test score & 0.008 & 0.014 *** & 0.014 *** & 0.007 ** \\
\hline Age $45-50 *$ test score & 0.013 ** & $0.023 * * *$ & 0.021 *** & $0.012 * \star *$ \\
\hline Age $50-55 *$ test score & 0.005 & 0.018 *** & 0.018 *** & 0.007 * \\
\hline Age $55-60 *$ test score & -0.001 & 0.014 ** & 0.016 ** & 0.009 * \\
\hline Age $60-65 *$ test score & 0.027 ** & 0.041 *** & 0.041 *** & 0.020 ** \\
\hline Age over $65 *$ test score & 0.020 & 0.028 ** & 0.018 & -0.004 \\
\hline Constant Term & $10.388 * * *$ & $10.349 * * *$ & 10.344 *** & $4.285 * \star *$ \\
\hline
\end{tabular}

Note: *** denotes significantly different from zero at the $1 \%$ level, ** at the $5 \%$ level, and * at the $10 \%$ level. The dependent variable is in log dollars. 
Appendix Table 2

Coefficients of controls in wage regressions

\begin{tabular}{|c|c|c|c|c|}
\hline \multirow[b]{2}{*}{ Estimation method: } & \multicolumn{4}{|c|}{ Manufacturing Workers } \\
\hline & Fixed Effects & Random Effects & $\begin{array}{c}\text { Random Effects } \\
\text { with AR (1) }\end{array}$ & System GMM \\
\hline Lagged earnings & -- & -- & -- & 0.564 *** \\
\hline 2 Years Since Displacement & 0.024 & -0.065 & -0.129 & 0.181 \\
\hline 3 Years Since Displacement & 0.205 & 0.072 & 0.011 & $0.367 * \star *$ \\
\hline 4 Years Since Displacement & 0.211 & 0.039 & -0.040 & 0.258 ** \\
\hline 5 Years Since Displacement & 0.240 & 0.029 & -0.060 & 0.230 *** \\
\hline 6 Years Since Displacement & 0.225 & -0.023 & -0.120 & 0.200 ** \\
\hline 7 Years Since Displacement & 0.232 & -0.050 & -0.153 & 0.196 ** \\
\hline 8 Years Since Displacement & 0.232 & -0.083 & -0.192 & 0.167 ** \\
\hline 9 Years Since Displacement & 0.186 & -0.162 & -0.275 & 0.099 \\
\hline 10 Years Since Displacement & 0.155 & -0.224 & -0.343 & 0.074 \\
\hline 11 Years Since Displacement & 0.092 & -0.316 & -0.444 & \\
\hline Male * 1 year & -0.269 & -0.125 & -0.181 & -0.226 \\
\hline Male * 2 years & 0.095 ** & $0.250 * \star *$ & 0.201 & $0.217 * \star \star$ \\
\hline Male * 3 years & 0.012 & $0.168 * \star \star$ & $0.138 * * *$ & $0.084 * \star *$ \\
\hline Male * 4 years & 0.057 & $0.210 * * *$ & 0.210 *** & 0.158 *** \\
\hline Male * 5 years & 0.039 & $0.193 * \star *$ & 0.202 *** & 0.117 *** \\
\hline Male * 6 years & 0.052 & $0.204 * \star \star$ & 0.218 *** & 0.142 *** \\
\hline Male * 7 years & 0.024 & $0.176 * * *$ & $0.191 * \star *$ & 0.103 *** \\
\hline Male * 8 years & 0.002 & 0.152 *** & 0.168 *** & $0.093 * * *$ \\
\hline Male * 9 years & 0.059 * & $0.209 * \star \star$ & $0.225 * * *$ & $0.164 * \star *$ \\
\hline Male * 10 years & 0.060 * & $0.210 * * *$ & 0.228 *** & 0.136 *** \\
\hline Male * 11 years & 0.067 & $0.217^{* \star *}$ & 0.238 *** & 0.148 ** \\
\hline Year 1995 & $-0.768 * \star \star$ & $-0.757 * \star \star$ & $-0.673 * \star *$ & 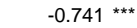 \\
\hline Year 1996 & -0.632 ** & $-0.581 * *$ & -0.504 ** & -0.190 ** \\
\hline Year 1997 & $-0.525 *$ & -0.436 & -0.358 & -0.137 * \\
\hline Year 1998 & -0.445 & -0.319 & -0.238 & -0.094 \\
\hline Year 1999 & -0.416 & -0.255 & -0.170 & -0.084 \\
\hline Year 2000 & -0.283 & -0.089 & 0.000 & 0.057 \\
\hline Year 2001 & -0.215 & 0.011 & 0.104 & 0.075 * \\
\hline Year 2002 & -0.279 & -0.023 & 0.074 & -0.007 \\
\hline Year 2003 & -0.327 & -0.042 & 0.057 & \\
\hline Age $40-45$ & 0.011 & -0.077 & -0.080 & -0.051 \\
\hline Age $45-50$ & $-0.165 * *$ & $-0.312 * \star \star$ & $-0.296 * \star \star$ & $-0.207 * \star \star$ \\
\hline Age $50-55$ & -0.160 & $-0.331 * * *$ & $-0.319 * * *$ & $-0.173 * * *$ \\
\hline Age $55-60$ & $-0.199 *$ & $-0.382 * \star *$ & -0.377 *** & $-0.226 * \star *$ \\
\hline Age $60-65$ & $-0.537 * * *$ & -0.712 *** & $-0.673 * * *$ & -0.345 *** \\
\hline Age over 65 & $-1.071 * * \star$ & $-1.126 * \star \star$ & $-0.884 * \star \star *$ & $-0.351 * *$ \\
\hline Age $40-45 *$ Tenure $6-10$ & $-0.125 * * *$ & -0.075 ** & -0.066 * & -0.052 ** \\
\hline Age $40-45 *$ Tenure $11-19$ & -0.116 *** & -0.008 & 0.003 & -0.017 \\
\hline Age $40-45 *$ Tenure over 20 & -0.179 & -0.038 & -0.009 & -0.100 \\
\hline Age $45-50 *$ Tenure $6-10$ & $-0.149 * * *$ & -0.054 & -0.026 & -0.007 \\
\hline Age $45-50 *$ Tenure $11-19$ & $-0.105 * *$ & 0.052 * & 0.066 * & $0.053 * *$ \\
\hline Age $45-50 *$ Tenure over 20 & -0.105 & 0.056 & 0.986 * & 0.020 \\
\hline Age $50-55$ * Tenure $6-10$ & -0.073 & 0.048 & 0.036 & 0.035 \\
\hline Age $50-55 *$ Tenure $11-19$ & -0.092 & 0.090 ** & 0.099 ** & 0.057 ** \\
\hline Age $50-55$ * Tenure over 20 & -0.090 & 0.072 & 0.078 * & -0.003 \\
\hline Age $55-60 *$ Tenure $6-10$ & -0.093 & 0.043 & 0.071 & 0.043 \\
\hline Age $55-60 *$ Tenure $11-19$ & -0.124 * & 0.053 & 0.078 & 0.051 * \\
\hline Age $55-60$ * Tenure over 20 & -0.273 & -0.119 ** & -0.099 * & -0.073 * \\
\hline Age $60-65 *$ Tenure $6-10$ & -0.054 & 0.079 & 0.085 & 0.013 \\
\hline Age $60-65 *$ Tenure $11-19$ & -0.093 & 0.079 & 0.107 & 0.058 \\
\hline Age $60-65 *$ Tenure over 20 & -0.145 & -0.012 & -0.050 & -0.006 \\
\hline Age over $65 *$ Tenure $6-10$ & 0.010 & 0.158 & 0.100 & 0.059 \\
\hline Age over $65 *$ Tenure $11-19$ & -0.040 & 0.115 & 0.017 & -0.023 \\
\hline Age over $65 *$ Tenure over 20 & $-0.589 * * *$ & $-0.511 * \star *$ & -0.548 *** & $-0.285 * *$ \\
\hline Age $40-45 *$ High School Dropout & 0.058 & -0.015 & -0.028 & -0.012 \\
\hline Age $40-45 *$ Some College & 0.104 *** & $0.101 * * *$ & 0.088 ** & 0.041 \\
\hline Age $40-45 *$ College Graduate & 0.016 & $0.207 * * *$ & $0.225 * * \star$ & 0.122 *** \\
\hline Age $45-50 *$ High School Dropout & 0.079 & 0.002 & -0.030 & -0.029 \\
\hline Age $45-50$ * Some College & 0.161 *** & 0.132 *** & 0.116 *** & 0.056 ** \\
\hline Age $45-50 *$ College Graduate & $0.148 * * *$ & $0.382 * * *$ & $0.400 * * *$ & $0.206 * * *$ \\
\hline Age $50-55$ * High School Dropout & -0.089 & $-0.157 * \star *$ & $-0.180 * \star *$ & $-0.106 * \star *$ \\
\hline Age $50-55 *$ Some College & $0.190 * * *$ & $0.147^{* * *}$ & $0.118^{* \star *}$ & 0.038 \\
\hline Age $50-55$ * College Graduate & 0.108 * & $0.377^{\star \star \star *}$ & $0.386 * \star \star$ & $0.166 * * *$ \\
\hline Age $55-60$ * High School Dropout & -0.048 & $-0.095 *$ & -0.117 ** & -0.038 \\
\hline Age $55-60$ * Some College & 0.111 & 0.069 & 0.082 & 0.010 \\
\hline Age $55-60 *$ College Graduate & 0.087 & $0.365 * * *$ & $0.377 * * \star$ & $0.150 * * *$ \\
\hline Age over 65 * High School Dropo & -0.193 ** & $-0.213 * * *$ & $-0.173 * *$ & -0.083 \\
\hline Age over $65 *$ Some College & 0.048 & 0.028 & 0.021 & -0.023 \\
\hline Age over 65 * College Graduate & -0.128 * & 0.116 * & 0.160 ** & 0.008 \\
\hline Age $40-45 *$ test score & 0.007 & 0.011 ** & 0.011 * & 0.006 * \\
\hline Age $45-50 *$ test score & $0.019 * *$ & $0.027^{\star * *}$ & $0.024 * \star \star$ & $0.014 * * \star$ \\
\hline Age $50-55 *$ test score & 0.012 & $0.021 * * *$ & $0.022 * \star *$ & $0.009 * *$ \\
\hline Age $55-60 *$ test score & 0.013 & 0.024 *** & 0.022 *** & 0.013 ** \\
\hline Age $60-65 *$ test score & 0.030 ** & $0.042 * * *$ & $0.041 * * *$ & $0.017 * *$ \\
\hline Age over $65 *$ test score & 0.027 & $0.034 * *$ & 0.021 & -0.005 \\
\hline Constant Term & 10.466 *** & $10.446 * * *$ & 10.441 *** & $4.315 * * *$ \\
\hline
\end{tabular}

Note: *** denotes significantly different from zero at the $1 \%$ level, ** at the $5 \%$ level, and * at the $10 \%$ level. The dependent variable is in log dollars. 